\title{
VARIABILITY IN LIFE-HISTORY CHARACTERISTICS OF STEELHEAD TROUT (Salmo gairdneri) ALONG THE PACIFIC COAST OF NORTH AMERICA
}

\section{by}

IRA LEWIS WITHLER

B. A. University of British Columbia, 1954

A THESIS SUBMITTED IN PARTIAL FULFILMENT OF THE REQUIREMENTS FOR THE DEGREE OF

MASTER OF SCIENCE

\author{
in the Department \\ of \\ ZOOLOGY
}

We accept this thesis as conforming to the required standard 
In presenting this thesis in partial fulfilment of the requirements for an advanced degree at the University of British Columbia, I agree that the Library shall make it freely available for reference and study. I further agree that permission for extensive copying of this thesis for scholarly purposes may be granted by the Head of my Department or by his representatives. It is understood that copying or publication of this thesis for financial gain shall not be allowed without my written permission.

Department of Zoology

The University of British Columbia, Vancouver 8, Canada.

Date October 2, 1961 


\section{ABSTRACT}

This study compares life-history characteristics of steelhead populations within a restricted area of the southwest coast of British Columbia, and within streams of the Pacific coast from central California to British Columbia. Variations observed within features of the life-histories of steelhead trout are related to physical features of stream environments and to the geographical location of study streams.

Within British Columbia data relating to time of stream entry, sex ratios, repeat spawning, mean lengths and duration of fresh and salt-water residence of winter and summer steelhead have been obtained from samples voluntarily submitted by anglers. Data relating to study streams have been obtained from map study, personal observation and through the courtesy of various governmental and municipal agencies. Several published studies from the coastal United States have permitted comparison of steelhead populations over a wide geographic range.

Within a limited area steelhead enter and ascend spawning streams throughout all months. Fish which enter streams between October 1 and April 30 are termed "winter steelhead", while "summer steelhead" enter streams between May 1 and September 30. Cheakamus River is exceptional in that initial stream entry of winter steelhead is delayed until April 1, with most fish entering during April and May. Late entry is related to delayed freshet conditions within the stream.

Almost twice as many female as male steelhead were angled. Comparison with trapping results suggests that sport fisheries 


\section{iii}

select for females of anadramous rainbow trout populations. Repeat spawning of winter steelhead was found to range from 5.0 percent for fish from the Seymour River to 31.3 percent for Cheakamus River. Repeat spawning among summer steelhead ranged from 4.4 percent (Seymour River) to 6.3 percent (Coquihalla River).

Mean fork lengths of steelhead populations of winter and summer steelhead showed little variation (range 26.3 to 31.0 inches). Winter steelhead from the Cheakamus River were larger than fish from all other populations, and summer steelhead from the Coquihalla River had the least mean length. Mean fork lengths of winter and summer steelhead were not significantly different, despite the five to eight month shorter term of salt-water residence of the latter. Variations of mean lengths of steelhead among different river systems is a result of differences in mean time of salt-water residence. Mean lengths increase with increased salt-water residence. Steelhead spent from one to four years in fresh water and from one to four years in salt water.

Along the Pacific coast from Central California to southern British Columbia, timing of initial stream entry showed little variation and the sex ratio was near one male to one female. Repeat spawning decreases from south to north. Mean fork lengths of steelhead populations are greater and fish spend more years in fresh and more years in salt water in 
northern areas. Possible factors causing variations in life history characteristics of steelhead along the Pacific coast are discussed. 
TABLE OF CONTENTS

Page

TITLE PAGE . . . . . . . . . . . . . . . . . . . . i

ABSTRACT . . . . . . . . . . . . . . . . . $i i$

TABLE OF CONTENTS . . . . . . . . . . . . . . V V

LIST OF FIGURES . . . . . . . . . . . . . . v viii

LIST OF TABLES • . . . • • • • • • • . . . .

ACKNOWLEDGEMENTS . . . . . . . . . . . . . . . .

INTRODUCTION $\quad$ • . . . . . . . . . . . . . 1

MATERIALS AND METHODS . . • . • . . . . . . . 4

The Study Streams . . . . . . . . . . . 4

British Columbia Streams . . . . . . 4

Pacific Coast Streams . . . . . . . 5

Sampling and Scale Reading . . . . . . . 5

Some Limitations of Angler Sample Methods . . 8

STEELHEAD POPULATIONS OF THE SOUTH COAST OF

BRITISH COLUMBIA • . . . . . . . • • • . . . 12

The Streams . . . . . . . . . . . . 12

Location . . . . . . . . . . . . 12

Water Flow (Volume) Characteristics . . . 12

Water Temperature Characteristics . . . . 13

Physical Characteristics . . . . . . 18

Coquitlam River . . . . . . . . 20 
Alouette River • . . . . . . . . 21

Chehalis River . . . . . . . . . 21

Chilliwack River . . . . . . . . 22

Coquihalla River . . . . . . . . . 22

Capilano River • . . . . . . . . 23

Seymour River . . . . . . . . . 24

Cheakamus River • . . . . . . . 25

Steelhead Populations . . . . . . . . 26

Timing of Stream Entry of Adult Steelhead 26

Winter Steelhead . • . . . . . . 27

Summer Steelhead • . • . • • • . . 29

Sex Ratios . . . . . . . . . . . 32

Winter Steelhead . . . . . . . . 32

Summer Steelhead . • . . . . . . 33

Repeat Spawning . . . . . . . . . . . 34

Winter steelhead . • . . . . . • . 34

Summer Steelhead . . . . . . . . 35

Lengths of Adult Steelhead • • . • • • 38

Winter Steelhead . . . . . . . . 38

Summer Steelhead • . . . . . . . . 40

Life-History Categories . • . • • . • 42

Winter Steelhead . • . . . • . • 42

Summer Steelhead . . . . . . . . 45

STEELHEAD POPULATIONS OF THE PACIFIC COAST . • • 51

The Streams . . . . . . . . . . . . 51 
vii

Page

Wadde11 Creek, California . . . . . . 51

Alsea River, Oregon . . . . . . . . 55

Streams of Coastal Oregon . . . . . . 56

Green River, Washington . . . . . . 56

Capilano River, British Columbia • • • . 57

Steelhead Populations . . . . . . . . . 58

Timing of Runs . . . . . . . . . . 58

Sex Ratios and Repeat Spawning . . . . . 59

Lengths and Life History Categories . . . . 62

DISCUSSION

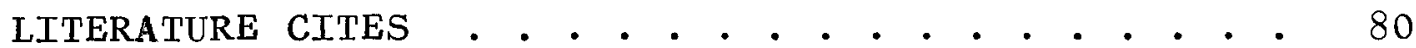


Figure 1. Location of the British Columbia study

Page

streams. . . . . . . . . . . . . 14

Figure 2. Mean monthly water flow (volume) for all streams for which data are available . . 15

Figure 3. Mean monthly water temperatures for all streams for which data are available . . 16

Figure 4. Profiles of the study streams. Broken lines represent upper limit of stream frequented by adult steelhead . . . . . 17

Figure 5. Numbers of steelhead captured in halfmonthly intervals for streams maintaining winter-run steelhead only (broken line represents division to early and late portions of winter run of steelhead). Ratios represent total numbers of male: female steelhead captured... . . . 28

Figure 6. Numbers of steelhead captured in halfmonthly intervals from streams maintaining summer and winter runs (broken line represents division to early and late portions of winter run of steelhead). Ratios represent numbers of male:female steelhead captured during winter and summer runs. . . 30

Figure 7. Life-history categories of winter steelhead captured within each British Columbia study stream (except Cheakamus River), represented by month as a percent of total captures, for all years of record, 1949 to 1958

Figure 8. Life-history categories of summer steelhead captured within British Columbia study streams, represented by month as a percent of total captures, for all years of record, 1949 to 1958 . . . . . . . . . . . . .

Figure 9. Location of the Pacific coastal study streams . . . . . . . . . . . . . 42 
Figure 10. Mean monthly water temperatures for a complete year of record for some coastal study streams . . . . . . . 54

Figure 11. Schematic representation of changes in life-history attributes of steelhead populations and mean stream temperatures along the Pacific coast. Thick portions of the pointers suggest greatest frequency or amount of an attribute, thin portion, the least. . . . . . . . . 
Table I Physical characteristics of the British Columbia study streams . . . . . . .

Table II Numbers of repeat spawning winter stee1head captured from British Columbia streams for all years of record, 1949 to 1958 . . . . . . . . . . . . .

Table III Numbers of repeat spawning summer steelhead captured from British Columbia streams for all years of record, 1949 to 1958 . . . . . . . . . . . .

Table IV Mean fork lengths of summer and winter steelhead in half-monthly intervals for all years of record, 1949 to 1958 . Lengths in inches . . . . . . . . . 39

Table V Life-history categories of winter and summer steelhead captured from the British Columbia study streams for all years of record, 1949 to 1958 . . . . . . . . 43

Table VI Physical characteristics of Pacific coastal study streams . . . . . . . . 53

Table VII Sex ratios and frequency of repeat spawning of steelhead captured from coastal study streams . . . . . . . . 60

Table VIII Mean lengths and age composition of adult steelhead captured within coastal. study streams 


\section{ACKNOWLEDGEMENTS}

The author wishes to express his gratitude to Dr. P. A. Larkin for suggesting this problem and the manner in which it should be pursued and for his review of the completed manuscript.

Thanks are also due to the many agencies which have provided water temperature and flow data for streams of British Columbia and the United States; these are the British Columbia Electric Company, Greater Vancouver Water District, Department of Fisheries of Canada, International Pacific Salmon Fisheries Commission, Fish and Game Branch of the British Columbia Department of Recreation and Conservation, and the Surface Water Branch of the United States Department of the Interior. Scale samples were provided by the British Columbia Fish and Game Branch.

Finally, special thanks to Dr. T. G. Northcote, Dr. C. C. Lindsey and Mr. S. B. Smith for their worthy comments and critical review of this paper. 


\section{INTRODUCTION}

The steelhead trout ( $\underline{\text { Salmo }}$ gairdneri), distributed along the Pacific Coast from California to Alaska, is a highly valued sport fish and contributes substantially to commercial fisheries. In comparison to the extensive studies conducted on other commercially valuable salmonid species and equally or less important sport fish species, life history and habits of steelhead have been studied relatively little. There are several reasons. First, pre-smolt steelhead are, as yet, morphologically indistinguishable from completely stream resident rainbow trout. Second, adult fish are few in number. Third, their spawning habits make direct observations under normal field conditions extremely difficult. Also, angling success for steelhead is low.

Despite the difficulties inherent in biological studies relating to this species, several have been undertaken in Pacific coastal states and in British Columbia. Shapavalov and Taft (1954) conducted a comprehensive nine-year study of pre-smolt, smolt and adult steelhead at a counting fence on Wadde11 Creek, California. Chapman (1958)istudied the life history of smolt and adult steelhead in the Alsea River, Oregon. Also in Oregon, Bali (1958) considered differences amongst steelhead populations from different streams and related these differences to physical and geographical differences between the streams. 
Pautzke and Meigs (1940) have reported upon a tagging and life history study of the steelhead trout population of the Green River, Washington. Maher (1954) has established criteria for the accurate interpretation of smolt and adult steelhead scales, and has presented data regarding the life-history of steelhead in the Chilliwack River, British Columbia. Also in British Columbia, Neave (1949) has studied the game-fish populations, including steelhead, of Cowichan River, Vancouver Island; and Milne (1948) has described the internal anatomy of the adult forms of this species. Larkin (1948) has compared the commercial catch of steelhead of the Fraser River system with anglers' returns from the $\mathrm{C}_{\text {hilliwack }}$ River.

No published information presently is available relating to steelhead trout populations of Alaska.

The investigations cited above have shown that the lifehistory characteristics of the steelhead are variable and Bali (1958) has suggested that steelhead populations of Oregon streams may vary in relation to their geographic distribution. The objectives of the present study are twofold. First, an attempt has been made to determine the characteristics of the steelhead trout populations of several streams in southwestern British Columbia, to determine what similarities and : differences exist among different populations and to determine what relationships exist between the characteristics of the population and their different fresh-water environments. Second, data relating to steelhead populations from coastal 
states and British Columbia have been compared to emphasize the variation which exists between populations. Characteristics which differ between Pacific coastal populations have been compared in relation to the latitudinal location of the streams from which they have been obtained. 
MATERIALS AND METHODS

THE STUDY STREAMS

British Columbia Streams

The geographical location, length, gradient, size of drainage area and other gross physical features of each British Columbia stream studied have been obtained from detailed topographical maps. Water temperature and flow data for each stream have been obtained from every source where extensive, accurate recordings were available. Water temperature and flow records for the Capilano and Cheakamus Rivers for a complete year were supplied by the Department of Fisheries of Canada, for the Seymour River by the Greater Vancouver Water District and for the Chilliwack River by the International Pacific Salmon Fisheries Commission and the Water Resources Branch of the Canada Department of Northern Affairs and Natural Resources.

Water temperatures only for the Chehalis and Coquihalla Rivers were made available by the International Pacific Salmon Fisheries Commission and for the Alouette River by the British Columbia Fish and Game Branch. No water temperature or flow records were available for the Coquitlam River. The means of daily recordings of water temperatures and flows have been - recorded at monthly intervals.

In some instances, pertinent information from personal 
observation of physical features of the streams such as composition of the stream bed, gradient of the stream and points of obstruction or difficult passage have been included.

Pacific Coast Streams

Where steelhead populations have been compared over a wide geographic range, data relating to streams have been extracted from steelhead studies in California (Shapavalov and Taft, 1954), Oregon (Chapman, 1958) (Bali, 1958) and Washington (Pautzke and Meigs, 1940). Each study has included a brief description of the physical features of the streams which contain the populations studied. Water flow and temperature data have been included if they were available.

SAMPLING AND SCALE READING

Steelhead populations within southern British Columbia were selected for study where 100 or more scale samples were available from an individual stream. The populations of seven streams were selected on this basis. Also, data for populations of the Chilliwack River tabulated by Maher (1954) are presented.

The 1,374 adult steelhead scale samples used were obtained entirely through a system of voluntary submission by anglers from 1949 until 1958. In this sampling program, anglers were supplied with envelopes for return of scale samples taken from "just behind the back 'dorsal' fin, high up on the side". 
Locality and date of capture, length and weight of fish and remarks were recorded by the angler for each sample.

All samples had been prepared for reading by personnel of the Fish and Game Branch prior to commencement of this study. Methods of selection, mounting and magnification of scales were identical to those of Maher (1954).

Using the criteria for interpretation of markings of steelhead scales established by Maher (1954), scales were read to determine features of the life history. If it were impossible to determine accurately the fresh-water history for an individual fish owing to regenerated central areas or poor mounting technique, only the salt-water growth portions of the scale were interpreted and recorded. Approximately 25 percent of all samples submitted were recorded only partially on this basis. All scale samples were re-read one month after the initial reading. Agreement between readings was good.

The following information was tabulated for each fish: locality of capture, sample number, half-month of capture, year of capture, summer or winter steelhead, length, weight, sex, years spent in fresh water, years spent in salt water, number and years of previous spawnings, year of hatching. Steelhead which were captured between November 1 and April 30 were classed as winter steelhead; fish captured from May 1 to October 30 were called summer steelhead.

Steelhead are known to spend from one to four years in a river before migrating to sea as a smolt, and from one to four 
years in the sea before returning to fresh water as a maturing adult (Maher, 1954). The term "age group" is used to denote the combination of fresh and salt-water life to which a fish belongs. In tables and in the text, age groups are referred to as $2 / 3,4 / 1$, etc., the first number representing the time spent in fresh water in years, and the latter number the time spent in the ocean in years. Life-history categories of summer steelhead have been recorded similarly, although in each instance their ocean life is six or eight months shorter than designated by the number following the oblique stroke.

Fortunately, the method of presentation of life-history information and terminology relating to steelhead populations is fairly uniform. This has facilitated a comparison of data extracted from various studies of steelhead populations from streams of Pacific coastal states and British Columbia.

The study of steelhead populations within Waddell Creek, California, was undertaken between 1933 and 1942. Data from the Alsea River and other Oregon streams were collected from 1951 through 1956. The study of steelhead populations of the Green River, Washington, extended from 1936 to 1940. In British Columbia, data for the Chilliwack River were collected from 1948 until 1953 and the present study utilizes samples obtained between 1948 and 1957.

Unfortunately, there is little agreement in the time periods during which these various studies were undertaken and therefore climatological or physical conditions cannot be 
assumed to be strictly comparable. Probably studies have been undertaken during years when temperature conditions and precipitation have differed from mean conditions. Also other factors such as oceanographic conditions, fishing pressure, watershed logging, water withdrawal and pollution, which may have an effect upon the nature of streams and their populations, cannot be judged to be alike among streams, nor from one time period to another.

Despite the foregoing, populations have been compared on the assumption that characteristics of steelhead populations are fairly uniform each year within each stream. Maher (1954) has found for steelhead of the Chilliwack River that "... For the five year period studied, the age composition of the adult run was strikingly similar from year to year."

Because of the lack of information on summer steethead from streams other than in southern British Columbia, only winter steelhead are considered in the section of this work describing characteristics of populations from a wide geographic range.

SOME LIMITATIONS OF ANGLER SAMPLE METHODS

Use of angler samples for biological studies of fish populations has been criticized because of several possible sources of bias. Some of these objections are discussed below. 


\section{Selection of fastest growing fish}

Larkin et al (1951) have shown that the fastest growing rainbow trout in Paul Lake, British Columbia, were more readily angled than were slower growing individuals. This phenomenon undoubtedly reflects "selection by the fishery of the larger and faster growing yearlingsts

This selectivity will be largely inoperative in steelhead samples submitted by anglers because of the considerable size which steelhead have attained before entering the fishery. Most angled steelhead are too highly prized trophies to be returned to the water to "try for a larger one" There is, however, a tendency for anglers to report only larger fish.

\section{Lure selectivity}

The possibility exists that some types of commonly used steelhead lures, because of their size, are more attractive to larger or smaller steelhead. Lure selectivity probably is not significant in this study as all fish captured are of a size to effectively attack the largest lure used. Further, Larkin (1949) found for rainbow trout in Paul and Kootenay Lakes that although different types of lures were more effective in different seasons, there was no measurable selection for larger fish by any one type. Trout angled from Kootenay Lake were comparable in size to steelhead.

\section{Escape of large fish}

The steelhead samples utilized in this study were obtained 
from fish captured in relatively small, swift-flowing streams. Capture of large, active fish from these surroundings required considerable adeptness by the angler. Under these conditions the larger the fish hooked, the greater are its chances of escape. It is probable, therefore, that a greater proportion of small and medium sized rather than large fish relative to their absolute numbers, is captured.

This bias may be most pronounced with summer stee thead which are less mature sexually than winter steelhead and are reputed to be the more agressive fighters. Also, summer stee1head are often angled with lighter tackle than are winter steelhead.

\section{Selection of females}

A most serious consideration in the use of anglers' samples is the apparent selectivity by steelhead sport fisheries for females.

Trapping records for adult steelhead entering streams at various stations indicate that males and females enter streams in approximately equal numbers. Shapavalov and Taft (1954) at Waddell Creek, California, report that "the sex ratio for the Steelhead runs as a whole was one male to 1.1 females". Pautzke and Meigs (1940) have tabulated 1,107 males and 1,115 females for two years of trapping records of adult steelhead in Green River, Washington. Chapman (1958) records an "approximately 
1:1 ratio in first spawners for adult steelhead in the Alsea River, Oregon. Larkin (1951), regarding creel census records of rainbow trout from Paul Lake, British Columbia, has stated that "there is a significant preponderance of females in the catch for all ages of fish except yearlings", yet there was no preponderance of females or males in the spawning run.

Data presented in this study (Figures 5 and 6) and Larkin's data from Paul Lake suggest very strongly that sport fisheries select for females in anadramous and lake resident populations of rainbow trout.

This selection is in part related to appearance of angled steelhead.

Male steelhead appear to deteriorate in condition and appearance to a greater extent than do females as spawning approaches. During the later portion of the steelhead angling season there is an increased tendency for anglers to release alive the male steelhead captured. 
STEELHEAD POPULATIONS OF THE SOUTH COAST OF BRITISH COLUMBIA

THE STREAMS

Location

The eight study streams are situated in the extreme southwest coast of British Columbia (Figure 1). They drain, either directly or via the Fraser River, to the Pacific Ocean. Five of the rivers drain to the Fraser River at distances varying from 23 to 100 miles upstream of its mouth; these are the Coquitlam, Alouette, Chehalis, Chilliwack and Coquihalla Rivers. The three remaining streams emptying directly to the Pacific near to Vancouver are the Cheakamus, Capilano and Seymour Rivers.

Al1 these streams have relatively short water courses with steep gradients (see Table 1, Figure 4). However, reduced gradients and more meandering water courses are found in the lower reaches of the three rivers which flow through the Fraser River delta; these are the Coquitlam, Alouette and Chilliwack Rivers.

Water Flow (Volume) Characteristics

A complete year of water flow (volume) records for each of the study streams for which tiiis information is available is shown in Figure 2. Flow data for the Chehalis River were obtained during 1956, for the Chilliwack, Cheakamus and Seymour Rivers from October 1955 to September 1956, and for the Capilano 
River from October 1954 to September 1955.

With the exception of the Cheakamus River, flow characteristics are fairly similar for each stream. Typically, in Pacific coastal streams, water flows are extremely low during the mid-summer months owing to low precipitation and again in mid-winter months because of freezing conditions in the upper watersheds. Peak water flows occur in April, May and June when precipitation is high and ice and snow in headwater areas is melting. A lesser peak usually occurs in October and November when precipitation is again high.

The Cheakamus River is exceptional in that highest water flows occur from June to September, the normal period of lowest water flows for other coastal rivers. This anomalous situation results from mid-summer melting of glaciers situated near some tributary streams of the Cheakamus River.

Within the study streams, the lowest mean monthly water flow of 78 cubic feet per second was recorded for the seymour River during the month of August 1956; the highest mean month1y flow of 18,200 cubic feet per second was recorded for the Cheakamus River for the month of July 1956 (Figure 2). Water flow records are not available for all rivers.

Water Temperature Characteristics

A complete year of water temperature records for each of the study streams for which this information is available is shown in Figure 3. Temperature data for Chehalis, Chilliwack 


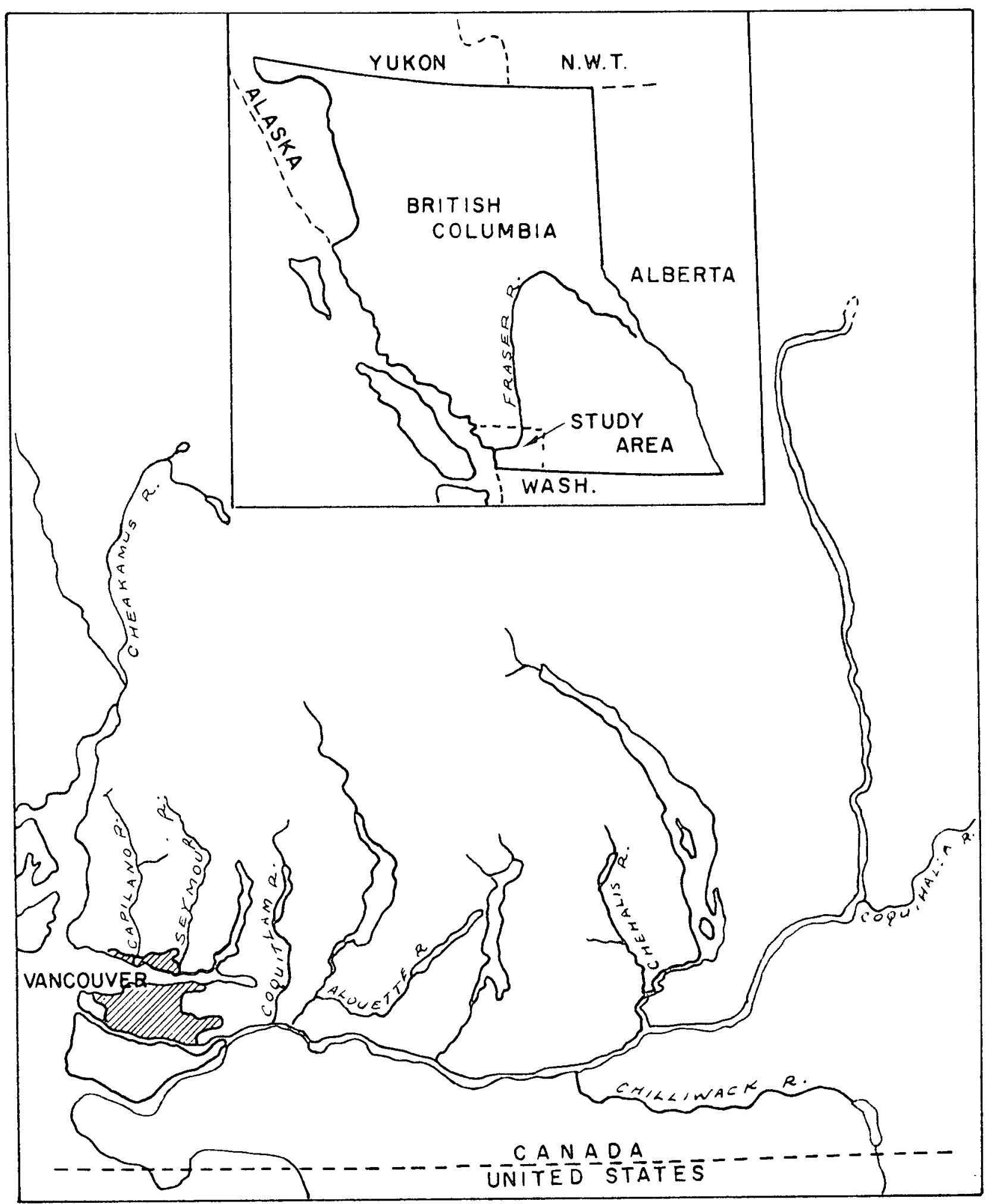

Figure 1. Location of the British Columbia study streams. 


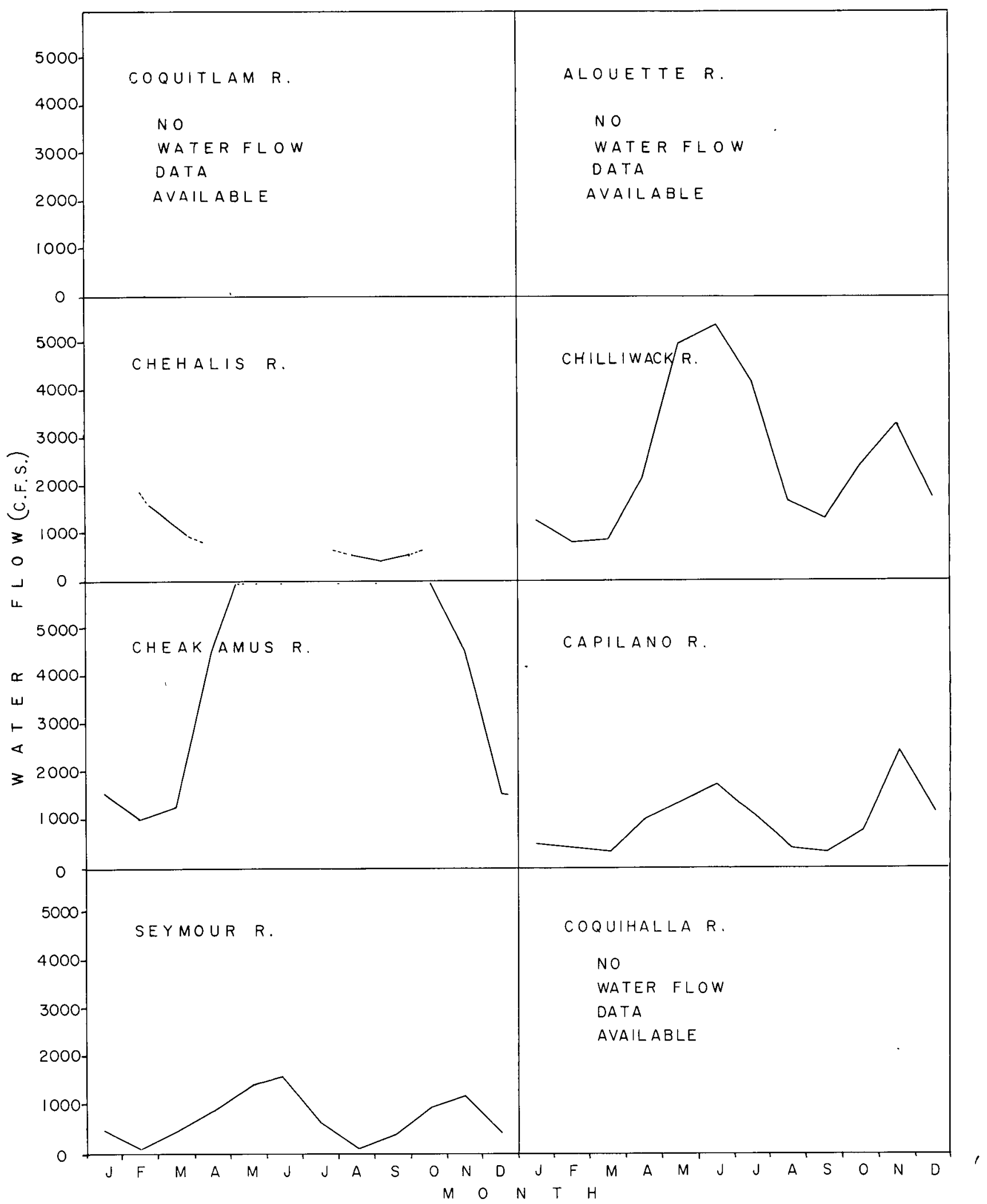

Figure 2. Mean monthly water flow (volume) for all streams for which data are available. 


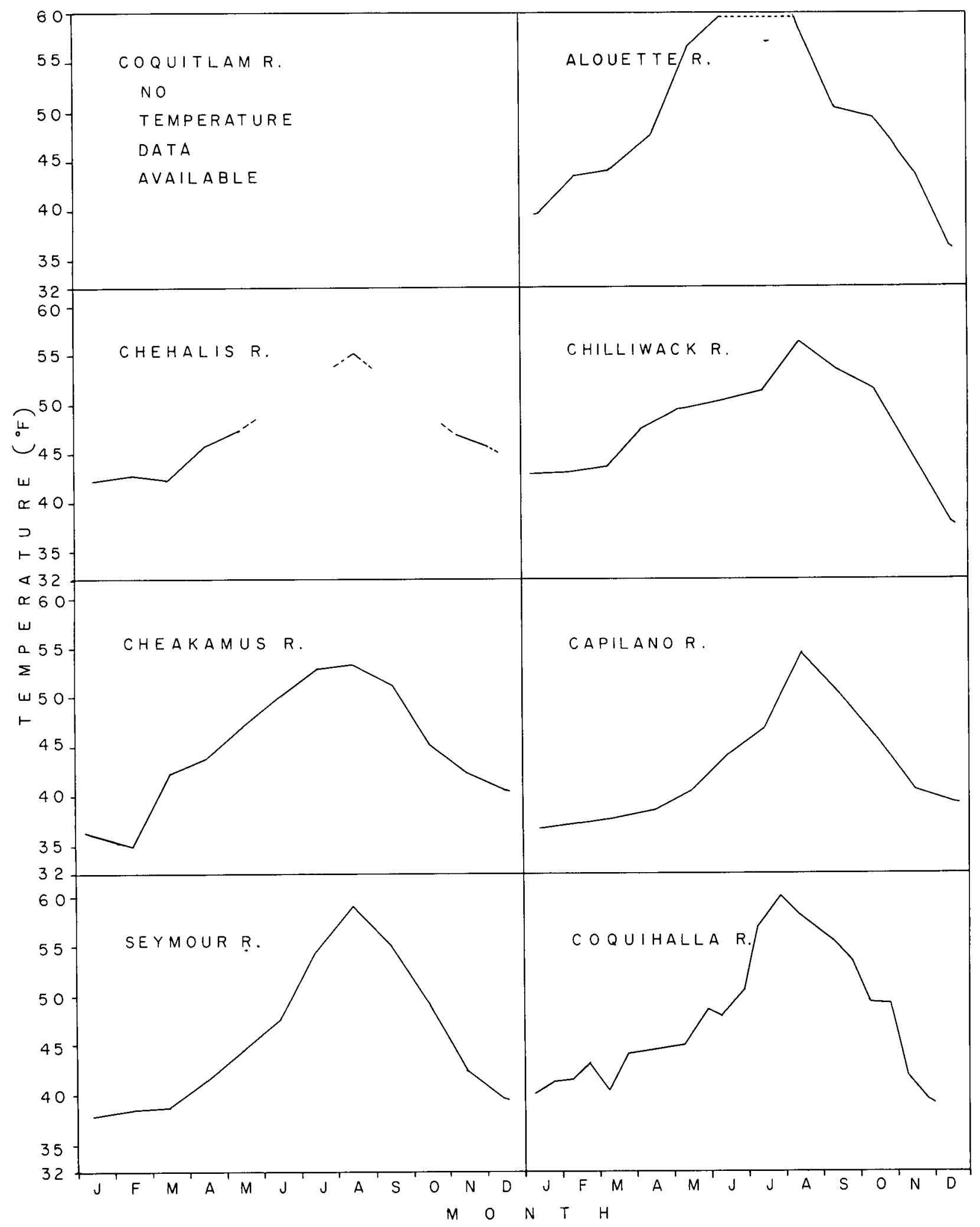

Figure 3. Mean monthly water temperatures for all streams for which data are available. 


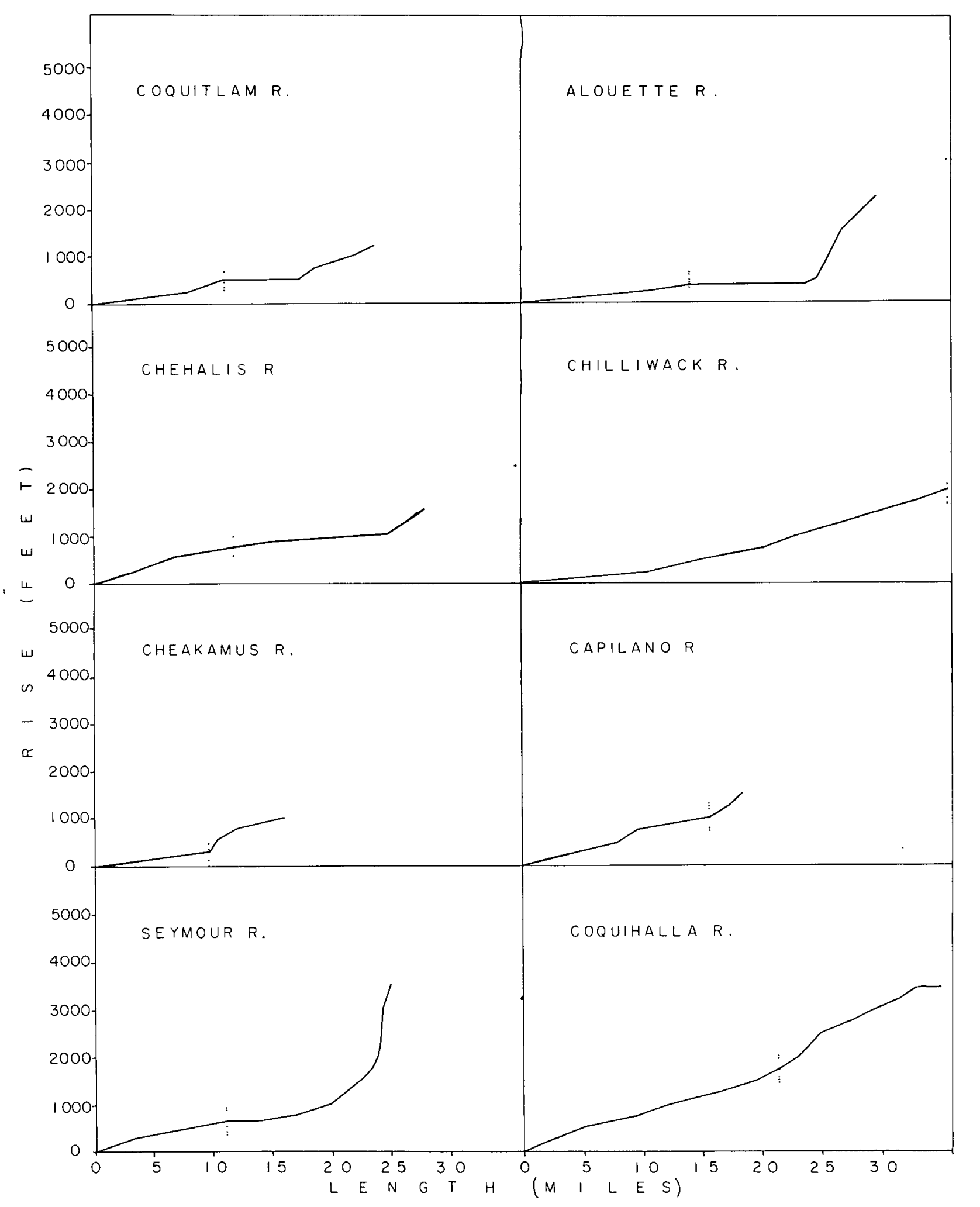

Figure 4. Profiles of the study streams. Broken lines represent upper limit of stream frequented by steelhead. 
and Cheakamus Rivers were obtained during the period January to December 1958, for Capilano River during 1951, for Alouette River during September 1960 to August 1961 and for Coquihalla River from January to August 1958, and September to December 1959. Data for the Seymour River represent mean temperatures from nine years of recording, 1951 to 1959.

In all rivers water temperatures are low (monthly means of $42^{\circ} \mathrm{F}$ or less) during the months of December, January and February. Mean temperatures begin to rise in March with a gradual increase until mid-August when mean temperatures range between $50^{\circ}$ and $62^{\circ} \mathrm{F}$. Water temperatures decrease during the fall and early winter months until mid-winter when means between $33^{\circ}$ and $42^{\circ} \mathrm{F}$ are experienced.

The lowest mean monthly water temperature of $33.2^{\circ} \mathrm{F}$ was recorded for the Cheakamus River in February 1957. The highest mean temperature of $56.6^{\circ} \mathrm{F}$ was recorded for the Seymour River during August (average from nine years of recording, Figure 3).

Physical Characteristics

The following section presents a brief description of some physical features of each stream which indicate stream differences, Gradients for each stream are shown in Figure 4. Some physical features of each stream are presented in Table I. The first five streams, arranged in order of increasing distances from the mouth of the Fraser River, flow to the Pacific Ocean via the Fraser River. The last three rivers described 
Table I. Physical Characteristics of the British Columbia Study Streams

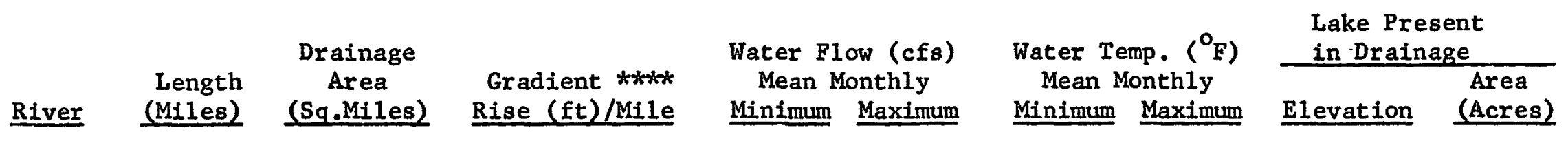

\begin{tabular}{|c|c|c|c|c|c|c|c|c|c|c|}
\hline Coquitlam & 37 & 77 & 68 & $* *$ & $* *$ & $x *$ & $* *$ & 350 & feet & 6000 \\
\hline Alouette & 27 & 79 & 34 & $* *$ & ** & $\begin{array}{l}36.6 \\
\text { Dec. }\end{array}$ & $\begin{array}{l}61.6 \\
\text { June }\end{array}$ & 384 & feet & 3994 \\
\hline Chehalis & 20 & 148 & 50 & $* *$ & $\hbar *$ & *t* & $* *$ & 750 & feet & 2500 \\
\hline Chill1wack & 50 & 450 & 57 & $\begin{array}{l}817 \\
\text { Feb. }\end{array}$ & $\begin{array}{l}5,350 \\
\text { June }\end{array}$ & $\begin{array}{l}34.0 \\
\text { Feb. }\end{array}$ & $\begin{array}{l}53.8 \\
\text { Aug. }\end{array}$ & 2,052 & feet & 2957 \\
\hline Cheakamus & 35 & 765 & 25 & $\begin{array}{r}1,030 \\
\text { Feb. }\end{array}$ & $\begin{array}{c}18,200 \\
\text { July }\end{array}$ & $\begin{array}{l}33.3 \\
\text { Feb. }\end{array}$ & $\begin{array}{l}51.1 \\
\text { Aug. }\end{array}$ & $*$ & & * \\
\hline Capilano & 22 & 68 & 66 *ม* & $\begin{array}{l}377 \\
\text { Mar. }\end{array}$ & $\begin{array}{l}2,370 \\
\text { Nov. }\end{array}$ & $\begin{array}{l}34.4 \\
\text { Jan. }\end{array}$ & $\begin{array}{l}52.0 \\
\text { Aug. }\end{array}$ & * & & * \\
\hline Seymour & 28 & 68 & 60 tht & $\begin{array}{c}78 \\
\text { Aug. }\end{array}$ & $\begin{array}{l}1,560 \\
\text { June }\end{array}$ & $\begin{array}{l}35.5 \\
\text { Jan. }\end{array}$ & $\begin{array}{l}58.0 \\
\text { Aug. }\end{array}$ & 650 & & 250 \\
\hline Coquihalla & 40 & 360 & $65 * * *$ & $* *$ & $* *$ & $\begin{array}{l}38.1 \\
\text { Jan. }\end{array}$ & $\begin{array}{l}56.2 \\
\text { Aug. }\end{array}$ & 3,750 & feet & 400 \\
\hline
\end{tabular}

\footnotetext{
* Reservoir established since conclusion of study period

** No information available

* Temporary barrier in stream

**** Gradient of stream to upper limit of steelhead ascent
} 
discharge directly to the ocean.

\section{Coquitlam River}

The Coquitlam River flows from the Coast Range of mountains to enter the Fraser River 23 miles upstream from its mouth. One major tributary stream, or (Gold) Creek, enters the river 11 miles upstream of the river mouth.

A dam to regulate the water levels in Coquitlam Lake for domestic and hydro-electric use, 12 miles upstream of the river mouth at the outlet of Coquitlam Lake, has been present since 1925. This dam has a considerable effect upon the regime of downstream water flows. Often, in the summer months no water passes the dam and downstream water flow is maintained entirely by or Creek. This volume is often in the order of 10 to 20 cubic feet per second. Gravel removal and washing operations contribute silt to the lower eight miles of the river.

The two factors outlined above, fluctuating water levels and industrial operations, probably prompt a rapid movement of adult steelhead upstream to the more stable environment of Or Creek. Also, as upstream migrants cannot pass over the diversion dam constructed at the lake outlet, it is commonly believed that the majority of adult fish spawn and pre-smolt steelhead are reared within Or Creek. 
Alouette River

The Alouette River flows to the Fraser River 25 miles upstream from its mouth. A major tributary stream, the North Alouette River, enters the river six miles upstream of the river mouth.

A dam at the outlet of Alouette Lake 13 miles upstream of the river mouth has controlled downstream water flows since 1925. Although flows past the dam are often eliminated, minimum flows of 20 to 30 cubic feet per second are maintained by contributions of small tributaries.

Steelhead ascend the river to the dam, an impassible barrier. Therefore, 13 miles of stream are available to adult and pre-smolt steelhead. The lower eight miles of river meander through the Fraser River delta and are suited to rearing of juvenile fish by reason of the relatively stable nature of pool and riffle areas. The upper five miles of accessible river are typically more precipitous and are composed of lengthy riffle areas and few pools. The river bed here is composed of coarser materials than are downstream areas.

\section{Chehalis River}

The Chehalis River flows to the Fraser River 53 miles upstream of its mouth. One large tributary stream, Statler Creek, is present seven miles upstream of the river mouth. The major steelhead spawning areas lie within the lower 
reaches of Statler Creek and the portion of Chehalis River above the junction of Statler Creek, but below Chehalis Lake.

Much of the lower five miles of the Chehalis River flows through steep-walled canyon areas containing deep pools. Water velocity is slow. Upstream, and in statler Creek, stream bed gradient is steep and water velocity greater. The stream bed is composed of large boulders and coarse rubble.

\section{Chilliwack River}

The Chilliwack River flows to the Fraser River 58 miles upstream from its mouth. Several tributary streams are present, but their precipitous nature precludes their use as steelhead spawning areas.

A section of Chilliwack River between 12 and 30 miles upstream of the river mouth, used by steelhead for spawning, has a moderate gradient with few pool or slack water areas. The bottom is composed largely of coarse gravel and boulders. The lower eight miles of the river are confined to a canal with a bed of mud and finely divided materials. In this area stream gradient and water velocities are greatly reduced.

\section{Coquihalla River}

The Coquihalla River flows to the Fraser River 100 miles upstream of its mouth. No major tributary streams are present.

A waterfall barrier, probably impassible for winter-run 
steelhead exists six miles upstream of the mouth of the river. Consequently, the spawning and rearing area for these fish is restricted to the lower six miles of stream. Near the mouth the river has a bed of coarse gravel and boulders and flows through shallow pool and riffle areas. Nearer the obstruction the river flows through deeper pools contained within deep rock canyons; here the stream bed is composed of bed-rock, coarse rubble and sand. Summer-run steelhead spawn and young fish are reared within 18 miles of river above the obstruction. Pools of moderate length and long riffle areas characterize this portion of the river. The river bed is composed largely of large boulders and coarse gravel.

\section{Capilano River}

The Capilano River flows to Burrard Inlet of the Strait of Georgia near to the mouth of the Fraser River. No tributary streams are present which are utilized for steelhead spawning.

A domestic water storage reservoir has been established approximately three miles upstream of the river mouth since 1954. Prior to reservoir construction, steelhead spawned in an area between three and six miles upstream of the river mouth. This area had a stream bed composed of boulders interspersed with coarse gravel, and because of its precipitous nature was the upper limit of upstream migration. This area 
has since been inundated to a depth of almost 300 feet by establishment of the reservoir. Steelhead are now trucktransported farther upstream to new spawning areas.

Several extensive pools are present downstream from the original spawning areas.

\section{Seymour River}

The Seymour River flows to Burrard Inlet some two or three miles to the east of Capilano River. No tributary streams which serve as steelhead spawning areas are present.

A domestic water supply storage dam is present 11 miles upstream of the river mouth. Only the stream downstream of the dam is available for steelhead. The river profile and bottom composition is similar to the Capilano River. A few large, deep pools are present. Elsewhere, the river bed is composed of large boulders and coarse gravel. Steelhead spawn in the upper five miles of accessible river.

accasionally, during summer months, no water flows past the storage dam. Undoubtedly, this irregular flow regime results in some stranding of fish immediately below the dam, and also in near lethal temperature conditions for some distance downstream. 


\section{Cheakamus River}

The Cheakamus River flows to the Squamish River and thence to Howe Sound of the Strait of Georgia, 30 miles north of Vancouver. One small tributary, Cheekye River, serves as a spawning ground for adult steelhead trout and as a rearing area for pre-smolt trout.

Water flow data from the Cheakamus River vary considerably from those of the other study streams (Figure 2). The Cheakamus exhibits a reversal of the normal mid-summer Iow flow pattern of most coastal streams. The period of high water volume extends from May until September, with a maximum mean flow in July. Flows are moderate in October and November and are lowest in February. The mid-summer and autumn water volume anomalies are a consequence of elevation of the portion of the watershed which most greatly influences flow within spawning areas. The usual spring and early summer snow melt is delayed at the elevation (2,000 - 3,000 feet) of the upper watershed area and consequently water volumes remain high during the summer months. During the autumn months much precipitation is bound in the form of snow within this area and consequently water flows are moderate during this period. Water temperature data are presented in Figure 3 . The Cheakamus River is unusual in that the recorded mean daily water temperature was lower from January 1 to February 15 (less than $34^{\circ} \mathrm{F}$ ) than for all other study streams for the years of record. Summer temperatures increased until mid- 
August and despite the high water volumes mean monthly temperatures during July and August were slightly greater than $50^{\circ} \mathrm{F}$.

Steelhead trout utilize the lower ten miles of the Cheakamus River for spawning. Numerous pool and slackwater areas are present within this area. The river bed is composed of boulders and coarse gravel. The gravel and boulders of the river bed are often displaced by the scouring action of occasional high water flows.

A hydro-electric diversion dam has been constructed upstream of the spawning area since conclusion of the study period.

\section{STEELHEAD POPULATIONS}

Timing of Stream Entry of Adult Steelhead

Figures 5 and 6 indicate that there is a marked variation in timing of adult steelhead entry into the streams studied. The timing of entry has provided a classification for different groups of steelhead. Depending upon the season during which adult steelhead enter streams, they are variously called winter (or winter-run) or summer (or summer-run) steelhead. As yet, no taxonomic criteria have been developed to differentiate these groups.

Steelhead which enter and ascend streams between early November and late March are named "winter" steelhead. However, 
in a few instances, winter fish have been reported captured as early as mid-October and occasionally winter steelhead which are late to ascend streams are captured in April. All winter-run fish have well-developed sexual products in preparation for spawning which takes place in March and April. Winter steelhead were captured in each of the study streams. Steelhead which enter and ascend streams during May, June, July and August are named "summer" steelhead. Summerrun fish have only slightly-developed gonads at the time of their entry to streams as spawning does not take place until early the following spring. Summer steelhead were captured in three of the eight streams studied. These streams are not closely related geographically. Two of the rivers supporting runs of summer steelhead (Capilano and Seymour Rivers) drain directly to the ocean via Burrard Inlet, while the Coquihalla River drains to the Fraser River 100 miles upstream of its mouth .

Timing of Winter Runs

Figure 5 shows the duration of the capture period and number of fish taken for winter steelhead angled within individual study streams. Most winter-run fish entered streams during January, February and March. The greatest number of steelhead were captured during January, with decreasing numbers captured in February and least numbers in March. This 

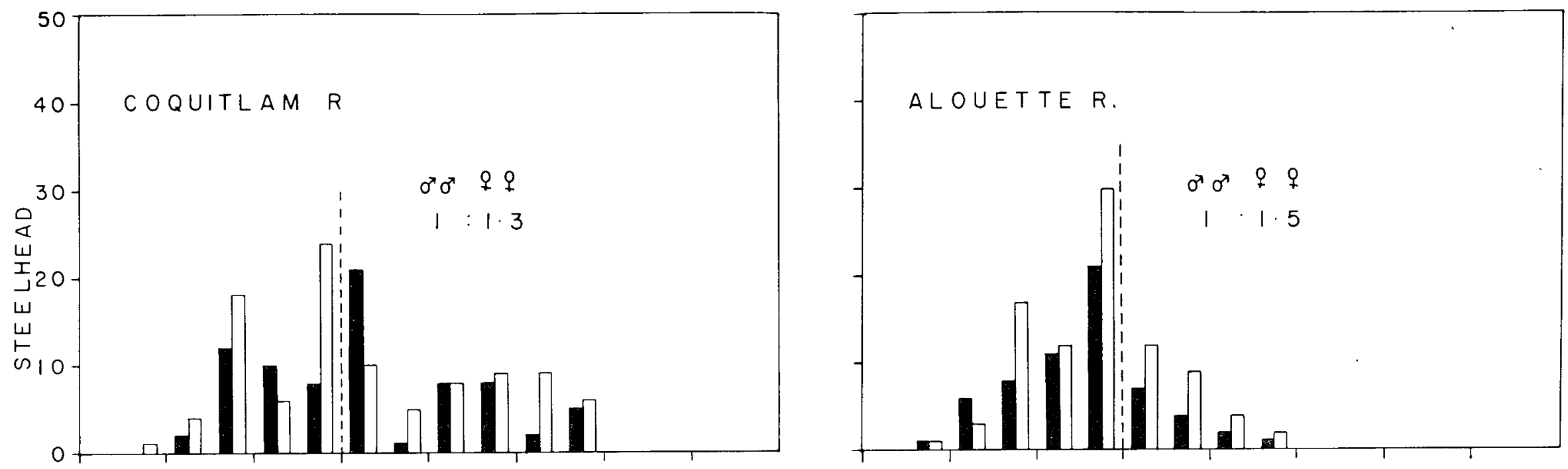

岁
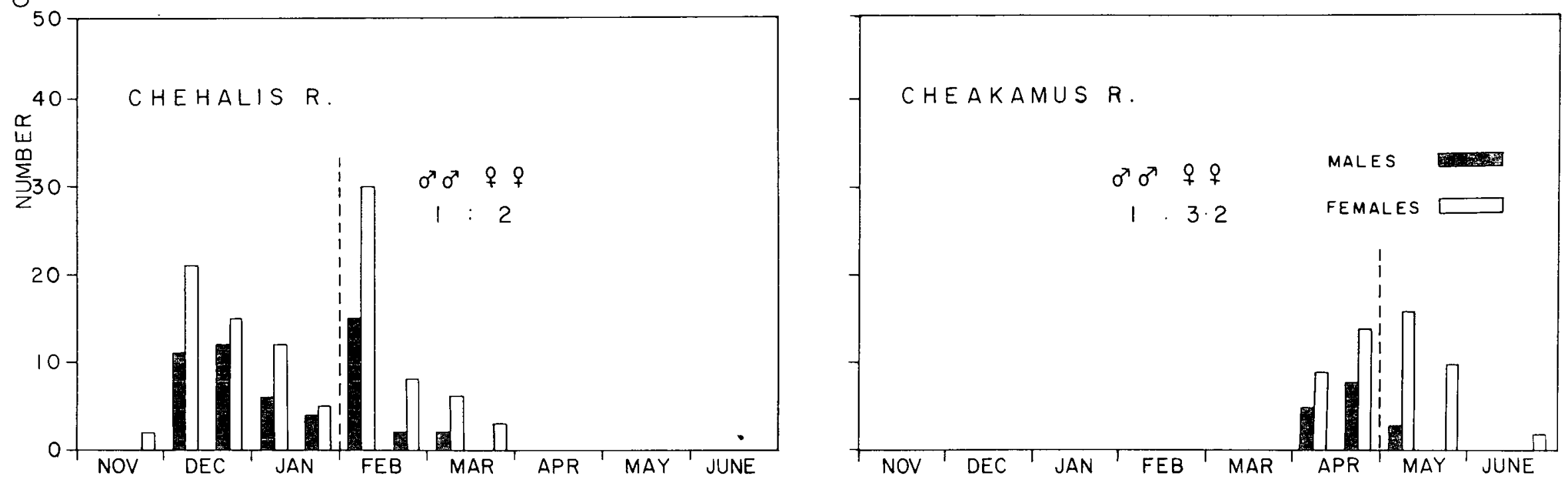

Figure 5. Numbers of steelhead captured in half-monthly intervals from streams maintaining winter-run steelhead only (broken line represents division to early and late portions of winter run of steelhead). Ratios represent total numbers of male:female steelhead captured. 
angling return information probably gives a fairly accurate index of the proportion of steelhead entering streams in various months. In the Capilano and Seymour Rivers, however, greater numbers of fish were captured during both February and March than during January. No steelhead were captured in the Cheakamus River during January, February or March in the three seasons of record available. In this stream all fish were captured during April and May.

Appreciable numbers of steelhead were captured from the Capilano, Alouette, Coquitlam and Chehalis Rivers during December. During the study period in the above streams 16.5 , $21.7,26.0$ and 37.5 percent respectively of the total numbers of fish caught during the period December to March were captured during December.

Timing of Summer Runs

The Capilano, Seymour and Coquihalla Rivers contained summer steelhead. Figure 6 shows the duration of the capture period and number of fish taken, within these streams. Timing of adult steelhead entry to the Capilano and Seymour Rivers is similar. Summer steelhead were first angled in these rivers during April and individuals were captured until late July. During April, steelhead entering the Capilano River trapping facilities are of two groups, distinguished by their degree of gonad development. Approximately one-half the fish 

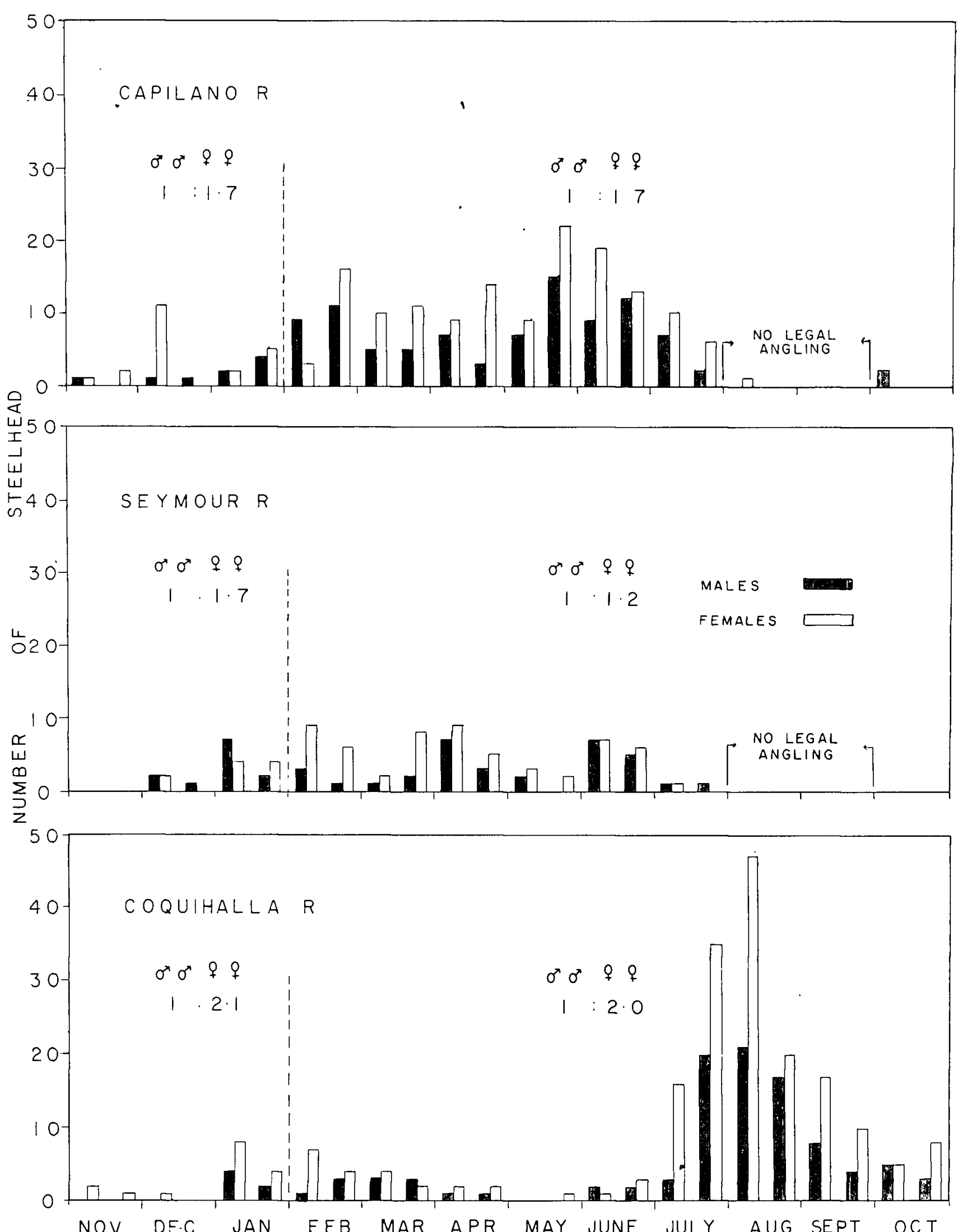

Figure 6. Numbers of steelhead captured in half-monthly intervals from streams maintaining summer and winter runs (broken line represents division to early and late portions of winter run of steelhead). Ratios represent numbers of male: female steelhead captured during winter and summer runs. 
have well-developed gonads in preparation for spawning which follows shortly; the remainder have only slightly developed gonads for spawning the following spring. The former group are "winter" steelhead which are late to enter the river; the latter are "summer" steelhead. Probably fish entering the Seymour River during April are in similar stages of deve1opment .

In the Capilano River approximately equal numbers of steelhead were captured during May and June, while in the Seymour River 27 of the 34 fish reported during these months were taken in June. In both rivers samples during July were considerably fewer than during the previous two months.

Summer steelhead of the Coquihalla River enter and ascend the stream later in the summer than do steelhead of the Capilano and Seymour Rivers. Steelhead first enter the river during late June. Their numbers increase until a peak is reached in mid-August; fewer fish are captured in September and only a very few fish are reported during october and November.

The three streams which maintain groups of both summer and winter steelhead support a fishery throughout almost all months of the year. Winter steelhead first enter these streams during December and fish continue to enter and ascend streams until April and May. During these latter months early summer-run fish are captured in small numbers. In the Coquihalla River a few summer steelhead are captured immedi- 
ately prior to the arrival of the first winter-run fish. A somewhat similar situation exists in the Capilano and Seymour Rivers. However, no steelhead were reported captured in the Capilano River and only a few from the Seymour River during August and September because of a fishery closure of much of the accessible river effective between August 1 and September 30 of each year.

The existence of populations of "Winter" and "summer" runs throughout their range is a unique feature of steelhead populations. This is a phenomenon not readily observed in Pacific salmon populations, although distinct "spring" and "fall" runs of Atlantic salmon in eastern Canada have been reported by various authors (Belding and Kitson, 1934) (Huntsman, 1939).

SEX RATIOS

winter Steelhead

Figures 5 and 6 show the sex ratio of adult steelhead captured within the study streams in two week intervals for the period of record. A striking feature of these data is that females almost invariably outnumber males. In the Chehalis and Cheakamus Rivers females outnumbered males captured in each half-month interval of the capture period. Number of males exceeded females captured during only one period in the Alouette and Coquihalla Rivers, and twice in 
the Coquitlam, Capilano and Seymour Rivers.

The greatest difference in ratio of males to females, 1:3.2, occurred in the Cheakamus River (Figure 5). Near equal numbers were angled in the Coquitlam River where the ratio was 1:1.3. In each instance females comprised between 56.5 and 76.1 percent of the total captures of winter steelhead.

The captures of adult winter steelhead for each of the study streams were arbitrarily divided into "early" and "late" stream entrants by grouping captures from November 1 to January 30 as early entrants, and captures from February 1 to April 30 as late entrants (divided by 'dotted' line in Figures 5 and 6 ). In the Cheakamus River the month of April served as the early part of the season; the month of May served as the late portion. Percentages of males captured in the early and late portions of the capture period were compared for each stream (Figures 5 and 6). Greater percentages of males were captured in the early portion of the capture period in the Alouette, Chehalis, Cheakamus and Seymour Rivers, and in the late portion in the Coquitlam, Capilano, and Coquihalla Rivers. No trend toward early or late entry of males or females was evident from this analysis.

\section{Summer Steelhead}

Ratios of males to females captured in summer fall within the range of the sex ratios for captures of winter steelhead in al1 study streams (Figure 6). 
Although these data show that many more female than male steelhead of both winter and summer runs are captured by anglers, trapping studies on other Pacific coastal streams strongly indicate that females are present in equal, or near equal, numbers to males.

\section{REPEAT SPAWNING}

Winter Steelhead

of 618 winter steelhead examined, 54 or 8.7 percent were returning to spawn for the second time and 11 or 1.8 percent for the third time (Table II). Second spawners were recorded from all the streams. Winter run steelhead returning to spawn for the third time were recorded from only four (Alouette, Coquitlam, Cheakamus, Coquihalla Rivers) of the seven study streams. No fish were recorded returning to spawn for a fourth time.

The greatest percentage of repeat spawners was recorded from the Cheakamus River; 31.3 percent of all winter steelhead captured during 1954, 1955 and 1957, the years of available record, were returning to spawn for a second or third time. The lowest return of repeat spawners was recorded from the Seymour River; 5.0 percent of all steelhead captured during the eight winter seasons from 1949-50 to 1956-57 were returning to spawn for a second or third time. In all streams except the Alouette and Cheakamus Rivers repeat spawning ranged between 
5 and 8 percent.

Table II shows that female repeat spawners predominate amongst the captures. In each stream except the Seymour and Coquihalla Rivers, where only two repeat spawners were captured, more second spawning females than males were captured. At least two and as many as nine female repeat spawners were captured for each male captured. Considering both second and third spawners, females represent 81.5 percent of all repeat spawners captured.

Summer Steelhead

of 302 summer steelhead examined 15 or 5.0 percent were returning to spawn for the second time and 1 or 0.3 percent for the third time (Table III). Second spawners were recorded from all of the study streams containing summer steelhead. One steelhead returning to spawn for a third time was captured in the Coquihalla River; no third spawners were reported from the Capilano or Seymour Rivers. Repeat spawning was observed in 4 to 7 percent of the captures from populations of summer steelhead.

As was found for winter steelhead, numbers of female repeat spawners greatly exceeded males. Eighty-nine percent of the repeat spawners were females. No male repeat spawners were captured in the Capilano or Seymour Rivers. 
Table II. Numbers of repeat spawning winter steelhead captured from British Columbia streams for all years of record 1949 to 1958.

\begin{tabular}{|c|c|c|c|c|c|c|c|c|}
\hline \multirow{3}{*}{ River } & \multirow{3}{*}{$\begin{array}{l}\text { Number } \\
\text { of Fish } \\
\text { in Sample }\end{array}$} & \multirow{3}{*}{$\begin{array}{l}\text { Number } \\
\text { of Repeat } \\
\text { Spawners } \\
\end{array}$} & \multirow{3}{*}{$\begin{array}{c}\% \\
\text { Repeat } \\
\text { Spawners }\end{array}$} & \multicolumn{2}{|c|}{ Second Spawners } & \multicolumn{2}{|c|}{ Third Spawners } & \multirow{3}{*}{$\begin{array}{c}\text { Ratio } \\
\text { Male/Female }\end{array}$} \\
\hline & & & & Male & Female & Male & Female & \\
\hline & & & & Nos. $\%$ & Nos. & Nos. & Nos: \% & \\
\hline
\end{tabular}

\begin{tabular}{|c|c|c|c|c|c|c|c|c|c|c|c|c|}
\hline Alouette & 132 & 19 & 14.4 & 3 & 2.3 & 12 & 9.1 & 2 & 1.5 & 2 & 1.5 & $1: 2.8$ \\
\hline Coquitlam & 148 & 8 & 5.4 & 1 & 0.7 & 4 & 2.7 & 0 & 0 & 3 & 2.0 & $1: 7$ \\
\hline Chehalis & 125 & 8 & 6.4 & 1 & 2.6 & 7 & 8.1 & 0 & 0 & 0 & 0 & $1: 7$ \\
\hline Chilliwack * & 754 & 44 & 5.8 & & & & & & & & & $1: 8$ \\
\hline Cheakamus & 64 & 20 & 31.3 & 1 & 1.6 & 16 & 25.0 & 1 & 1.6 & 2 & 3.1 & $1: 9$ \\
\hline Capilano & 77 & 6 & 7.8 & 2 & 2.6 & 4 & 5.2 & 0 & 0 & 0 & 0 & $1: 2$ \\
\hline Seymour & 41 & 2 & 5.0 & 1 & 2.5 & 1 & 2.5 & 0 & 0 & 0 & 0 & $1: 1$ \\
\hline Coquihalla & 31 & 2 & 6.4 & 0 & 0 & 1 & 3.2 & 0 & 0 & 1 & 3.2 & - \\
\hline
\end{tabular}

* Date from Maher, 1954 
Table III. Numbers of repeat spawning summer steelhead captured from British Columbia streams for all years of record 1949 to 1958 .

\begin{tabular}{|c|c|c|c|c|c|c|c|c|c|c|c|c|}
\hline \multirow[b]{3}{*}{ River } & \multirow{3}{*}{$\begin{array}{l}\text { Number } \\
\text { of Fish } \\
\text { in Sample } \\
\end{array}$} & \multirow{3}{*}{$\begin{array}{c}\text { Number } \\
\text { of Repeat } \\
\text { Spawners } \\
\end{array}$} & \multirow{3}{*}{$\begin{array}{c}\% \\
\text { Repeat } \\
\text { Spawners } \\
\end{array}$} & \multicolumn{4}{|c|}{ Second Spawners } & \multicolumn{4}{|c|}{ Third Spawners } & \multirow{3}{*}{$\begin{array}{c}\text { Ratio } \\
\text { Male/Eemale }\end{array}$} \\
\hline & & & & \multicolumn{2}{|c|}{ Male } & \multicolumn{2}{|c|}{ Female } & \multicolumn{2}{|c|}{ Male } & \multicolumn{2}{|c|}{ Female } & \\
\hline & & & & Nos: & \% & Nos. & $\%$ & Nos. & \% & Nos. & $\underline{\%}$ & \\
\hline Capilano & 99 & 6 & 6.1 & 0 & 0 & 6 & 6.6 & 0 & 0 & 0 & 0 & - \\
\hline Seymour & 45 & 2 & 4.4 & 0 & 0 & 2 & 4.4 & 0 & 0 & 0 & 0 & - \\
\hline
\end{tabular}




\section{LENGTHS OF ADULT STEELHEAD}

The mean fork lengths of male and female summer and winterrun steelhead captured within the study streams are shown for bi-monthly intervals in Table IV.

Winter Steelhead

The mean length was 28.4 inches for males and 28.2 inches for females. Within each stream males were of greater mean length than females except in the Coquitlam and Chehalis Rivers (Table IV). In the Coquitlam River females were 0.6 inches longer than males, while in the Chehalis River the difference in mean lengths was only 0.1 inch. Comparing lengths of samples from all study streams from which winter-run fish were captured, both males and females from the Cheakamus River had the greatest mean length, 31.0 and 30.2 inches respectively. Males with the least mean fork length (26.6 inches) were captured from the Coquitlam River, while females with the least mean length (26.9 inches) were captured from the Alouette River. Maher (1954), for the Chilliwack River suggests that "... in nearly all cases the mean male length and weight was slightly higher than that of the female..."

No large differences can be shown in mean lengths of males or females during the period of capture of winter-run steelhead within each study stream. There appears, however, to be a trend toward capture of smaller fish of both sexes during the 
Table IV. Mean fork lengths of summer and winter steelhead in half-monthly intervals for all years of record, 1949 to 1958. Lengths in inches.

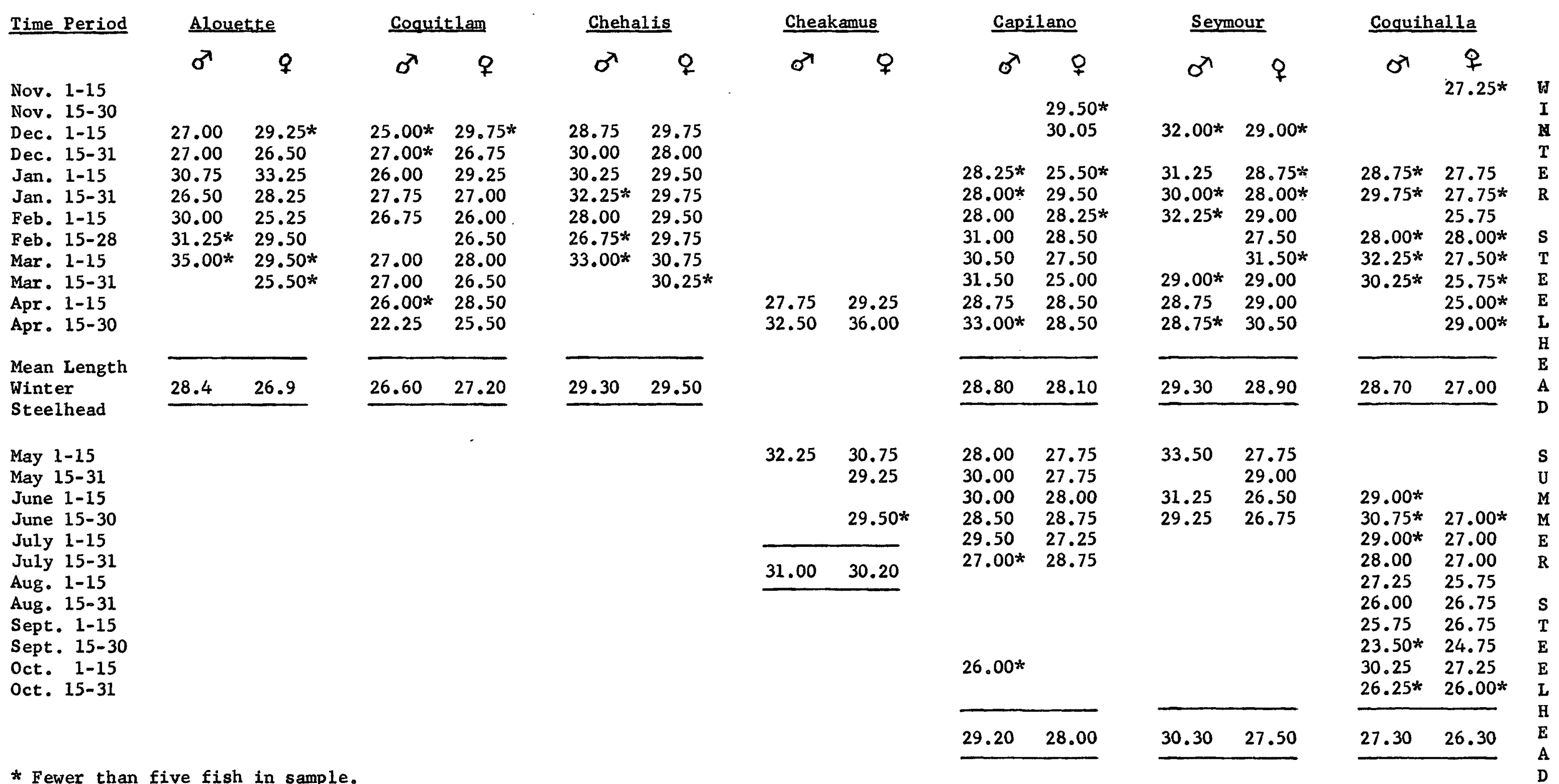


very early and late portion of the periods of record.

Summer Steelhead

Mean length of males was 28.2 inches, and of females was 26.9 inches. Within each study stream males were of greater mean length than females. The greatest difference in mean lengths was found in the Seymour River where males were 3.1 inches longer than females. Comparing lengths of samples from all study streams from which summer-run fish were captured, males from the Seymour River had the greatest mean length ( 30.3 inches), while females from the Capilano River had the greatest mean length (28.0 inches). Males (27.3 inches) and females (26.3 inches) with the least mean length were captured from the Coquihalla River.

Table IV indicates that considerable variability exists in mean length of summer steelhead captured in each bi-monthly period.

The mean length of male winter steelhead was 28.4 inches; male summer steelhead had a mean length of 28.2 inches. Female winter steelhead had an average length of 28.2 inches, while female summer steelhead had a mean length of 26.9 inches.

No length data for adult summer steelhead from other sources are available owing to the infrequency of occurrance of sizeable populations of these individuals. In the streams studied summer steelhead ascend streams five to eight months preceding the 
normal one to four complete years of ocean residence experienced by winter steelhead. Smith (personal communication) has sampled stomachs of summer steelhead from Coquihalla River; they were largely empty suggesting that little, or very restricted, feeding occurs in fresh water. Presumably growth in length ceases under these circumstances. Belding and Kitson (1934) found that a similar condition prevails with early-run and laterun Atlantic salmon. Measurements of salmon entering the Mirimichi River showed practically no difference in length between early and late-run fish, in spite of the longer sojourn and longer feeding period of the latter in salt water, indicating that the larger or more advanced salmon tended to enter the river earlier. 


\section{LIFE-HISTORY CATEGORIES}

Winter Steelhead

Table $\mathrm{V}$ indicates the life-history categories of winter steelhead from each of the study streams. Fourteen different life-history categories are represented. The greatest number of different life-history categories, ten, was represented by samples from the Alouette River; the least number, five, was obtained from the Capilano River.

Steelhead which had spent two or three years in fresh water (i.e., 2/, 3/) before migrating to the ocean and which had spent either two or three years in salt water (i.e., /2, /3), represent 91.6 percent of the total sample from all streams. Yearling smolts (1/) were found only in the Alouette River, where they represented only 8.4 percent of the samples. Steelhead which had migrated to the ocean as smolts at the age of two or three years were found from all streams and represented 39.9 percent and 54.9 percent respectively of total samples from all study streams. Four year old migrants were also captured from all study streams, but represented only 3.4 percent of all samples.

Greater numbers of smolts migrated to salt water at three than two years of age. Only in samples from the Alouette River (and from the Chilliwack River from data of Maher (1954)) were two year old migrants more numerous than three year old mig- 
Table V. Life-history categories of winter and summer steelhead captured from the British Columbia study streams for all years of record, 1949 to 1958 .

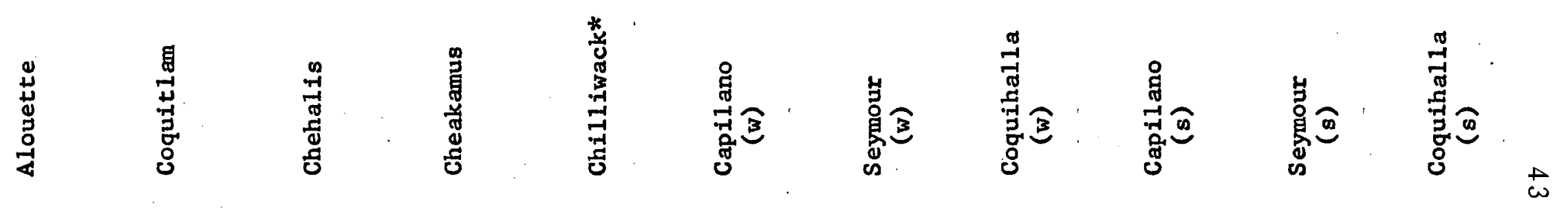

$1 / 1$

$1 / 2 \quad 3.3 \%$

$1 / 3 \quad 6.6 \%$

$1 / 4 \quad 2$ 1.5\%

$2 / 1 \quad 10.7 \%$

$\begin{array}{llll}2 & 42 & 34 & 9 \\ 32.1 \% & 23.3 \% & 8.2 \%\end{array}$

$\begin{array}{llrl}2 & 42 & 14 & 12 \\ 3 & 32.1 \% & 9.6 \% & 10.8 \%\end{array}$

$2 / 4 \quad 2$ 1.5\%

$3 / 1$

$\begin{array}{ll}3 / 2 & 21 \\ 16.0 \%\end{array}$

$16.0 \%$

72

$49.3 \%$

37

$33.3 \%$

$3 / 3 \quad 11.3 \%$

20

38

$3 / 4 \quad 10.8 \% \quad 4$

$\begin{array}{lll}1 & 2 & 3 \\ 0.9 \% & 3.2 \% & 0.4 \%\end{array}$

$4 / 1$

$4 / 2$

$\begin{array}{ll}4 / 3 & 1 \\ 0.8 \%\end{array}$

1

$9.1 \% \quad 1.6 \%$

$5.5 \%$

$1.6 \%$

$\begin{array}{ll}1 & 1 \\ 0.1 \% & 1.4 \%\end{array}$

3

$0.4 \%$

$3.4 \%$

$1.2 \%$

12

$11 \%$

${ }_{1.7 \%} \quad 2.1 \%$

$2.0 \%$
1

$0.7 \%$

$4 / 4$

$\begin{array}{lllllllllll}131 & 146 & 111 & 64 & 770 & 70 & 58 & 39 & 86 & 25 & 150 \\ 100 \% & 100 \% & 100 \% & 100 \% & 100 \% & 100 \% & 100 \% & 100 \% & 100 \% & 100 \% & 100 \%\end{array}$

\footnotetext{
* Data from Maher, 1954

(w) Winter steelhead

(s). Summer steelhead
} 
rants. In the Alouette River 65.7 percent of all steelhead sampled had migrated at two years of age, 25.1 percent had migrated at three years. In other streams three year old migrants represented between 52.9 percent (Capilano River) and 68.4 percent (Chehalis River) of all samples. In each stream, excluding the Alouette River, two year old migrants represented between 19.0 percent (Chehalis River) and 45.7 percent (Capilano River) of all samples.

AII winter steelhead captured had remained in salt water for a period of one to four years following migration from fresh water and prior to returning to fresh water to spawn. Individuals which had spent one year in salt water were uncommon ( 1.1 percent of the total sample). Steelhead which had spent four years in salt water represented 2.6 percent of the total sample. Two and three year salt - water resident fish represented 96.3 percent of the total sample. Fish with three years of salt-water existence represented 37.2 percent of the total sample, while two year ocean resident fish comprised 59.I percent of the total sample.

The youngest winter steelhead captured were of the $1 / 2$ age group; three of these were captured from the Alouette River. The oldest individuals captured were a total of eight steelhead from the Alouette, Chehalis and Coquihalla Rivers with a life-history category of $4 / 3$, and a total of eight steelhead from the Alouette, Coquitlam, Chehalis, Cheakamus and Seymour Rivers with 1ife-history categories of $3 / 4$. 
Figure 7 shows for each study stream the percentages (in monthly intervals) of winter steelhead represented by different major life-history categories. No trend toward early or late season entry of particular age groups may be noted. However, if differences in timing of stream entry by individuals of particular life-history patterns do in fact exist from month to month, this effect would tend to be masked by the grouping of captures from different years of record used to construct the composite figures illustrated. Also, use of angling as a sampling technique would tend to obscure modality which may exist by extending the capture period for a particular group of steelhead over several months.

Shapavalov and Taft (1954) found that representation of various age groups of winter-run steelhead within the run to Waddell Creek, California, is not the same throughout the season. The $/ 1$ fish of smaller size predominated in the early part (November, December, January) of the run; the $/ 2 \mathrm{fi}$ ish appeared in increasing numbers as the season progressed (February, March), and the larger / 1 fish increased in abundance during the late portion of the run (March, April). Similar phenomena have not been reported by other investigators.

Summer Steelhead

Table $\mathrm{V}$ shows the number and percentage of summer steelhead from each of the study streams with different life-history 

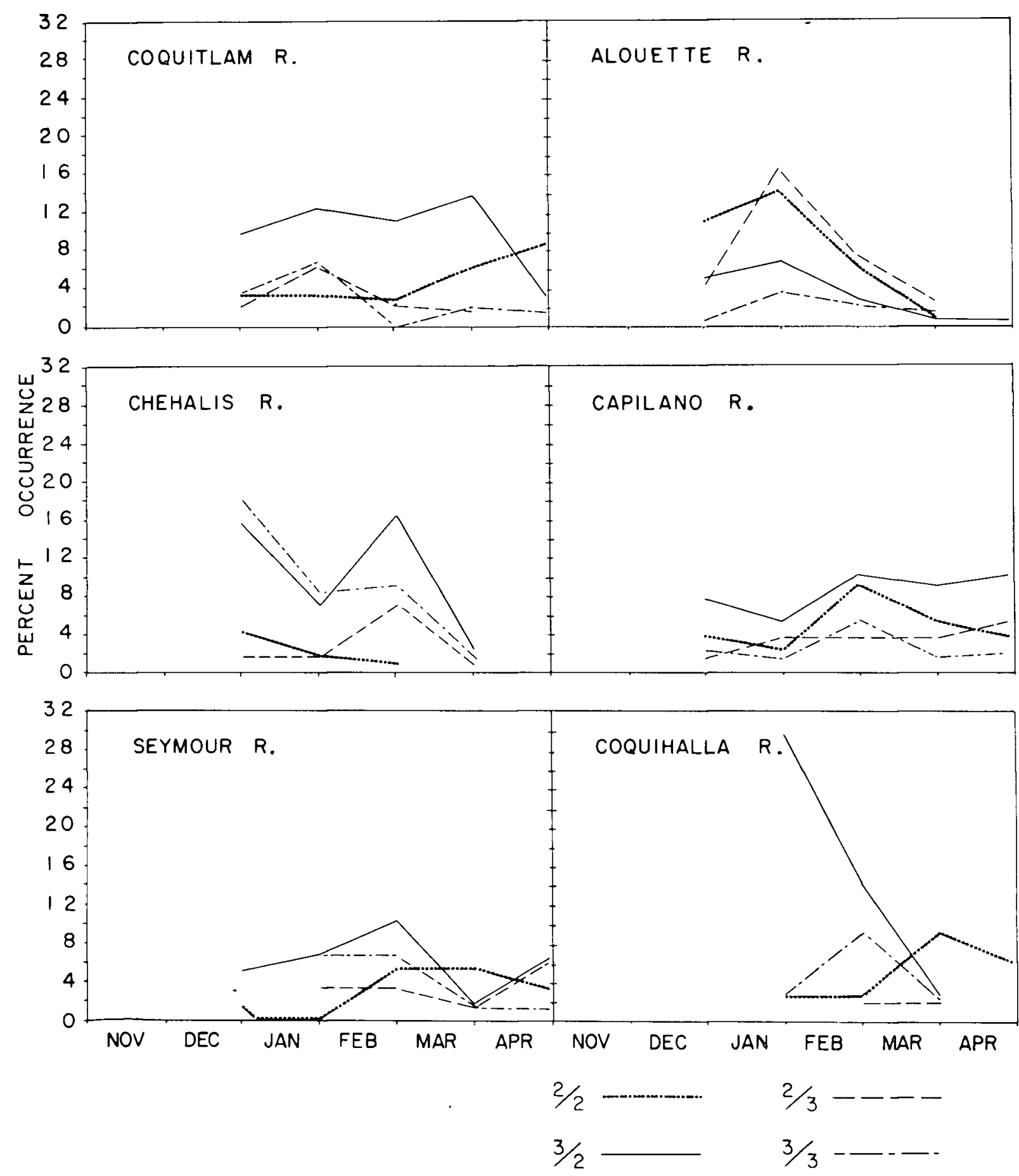

Figure 7. Life-history categories of winter steelhead captured within each British Columbia study stream (except Cheakamus River), represented by month as a percent of total captures, for all years of record, 1949 to 1958. 


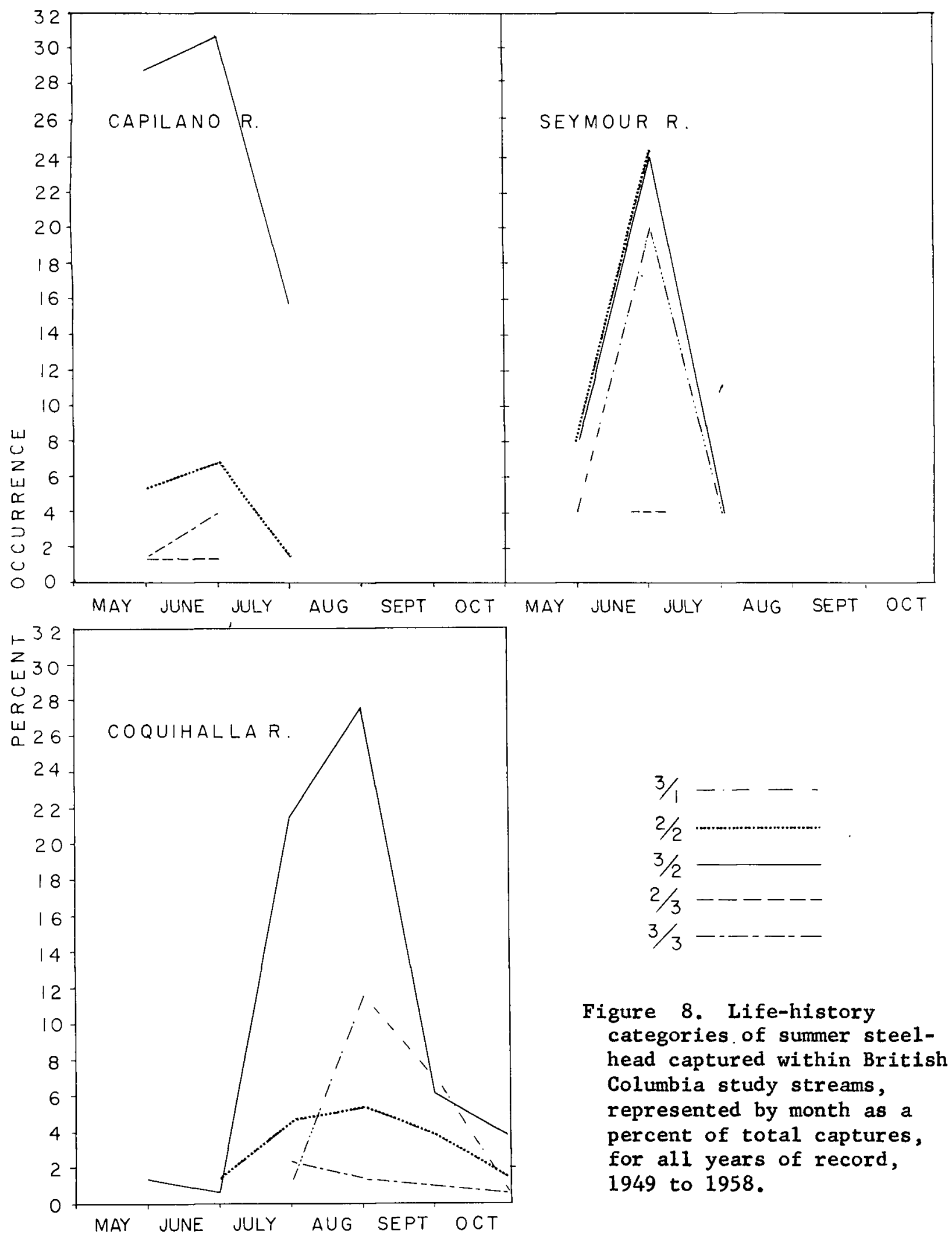


patterns. Ten different age classes are represented. The greatest number of age classes, nine, was represented by samples from the Coquihalla River; the least number, four, were from the Seymour River.

Summer steelhead which had spent two or three years in fresh water (i.e., 2/, 3/) before migrating to the ocean and which had spent one to four years in salt water (i.e., /1, /2, /3, /4) represented 95.6 percent of the total sample from all streams. Yearling smolts were found in the Capilano and Coquihalla River; they represented only 0.8 percent of all samples. Nine four-year-old smolts were recorded from the Coquihalla River; they represented 6.0 percent of all samples from that stream. Two-year-old seaward migrants represented 19.7 percent of all samples, while 75.9 percent were three-year-old migrants. Considerable variation exists in the percentages of each life-history pattern represented from stream to stream (see Table V). However, in all streams there are similar relationships among most life-history categories. For example, in each stream three-year-old migrants outnumber two-year-old migrants. Adult steelhead representing the life-history category $3 / 2$ were captured in greater numbers than were those of a $3 / 3$ pattern; and, except from the Coquihalla River, $2 / 3$ adults outnumbers $2 / 2$ adults.

A11 summer steelhead captured had remained in salt water from one to four years following migration from fresh water and 
prior to returning to fresh water to spawn. Only one individual had spent four years in salt water; this fish was of a $3 / 4$ Iife-history category and was from the Capilano River. Steelhead which had spent only one year in salt water were captured from the Coquihalla and Capilano River; the 19 fish in this category represented 7.4 percent of the total sample. Eighteen of these fish were obtained from the Coquihalla River. Summer steelhead of the $/ 2$ and $/ 3$ category constituted the bulk of the samples from all streams. Three-year salt-water residents comprised 20.4 percent of the total sample from all streams. Fish which had spent two years in salt water were in the majority; they represented 71.8 percent of the total sample. The ratio of fish which had spent two years in salt water to those which had spent three years in this environment is not constant among streams containing summer steelhead. In the Capilano River the ratio of $/ 3$ to $/ 2$ fish captured is $1: 1.3$, in the Seymour River $1: 1.8$ and in the Coquihalla River the ratio is $1: 15.5$. Also, as noted previously, a much higher percentage of fish which had spent only one year in salt water were captured from the Coquihalla River than from other streams.

Length at maturity is related to the length of salt-water residence of steelhead. Maher (1954) has shown that winter steelhead from the Chilliwack River attain a length of approximately 19 inches after one year of salt-water life, 28 inches after two years and 32 inches after three years. The shorter term of salt-water residence experienced by summer steelhead of 
the Coquihalla River is reflected in the smaller mean size at capture for these fish noted in the discussion of adult lengths. At capture, summer steelhead from the Capilano and Seymour Rivers were of 1.8 and 1.9 inches greater mean length than were those from the Coquihalla River.

The youngest summer steelhead captured were two individuals from the Capilano and Coquihalla Rivers with a 1/2 1ifehistory category and three fish from the Coquihalla River with a $2 / 1$ category. The oldest individual captured was one fish from the Capilano River with a life-history category of $3 / 4$.

The percentage of the total number of summer steelhead represented by different major life-history patterns captured in each study stream in monthly intervals is shown in Figure 8 . As was observed for winter steelhead, no trend toward early or late season entry of particular age groups is noted. Grouping of samples and the use of angling as a sampling method would again tend to obscure any modality which may be present among captures. Also, except in the Coquihalla River, the capture period is of shorter duration than for winter steelhead, thus making trends which might exist more difficult to observe. 
STEELHEAD POPULATIONS OF THE PACIFIC COAST

In the following section life-history characteristics of steelhead populations from a wide geographical range are considered. For this purpose populations from several streams of the Pacific Coast of North American from central California to southern British Columbia are compared.

\section{THE STREAMS}

The geographical location of the streams considered in this section is shown in Figure 9. Physical features of each stream are given in Table VI, and water temperatures for each stream, expressed as a mean of daily recordings at monthly intervals, are shown in Figure 10.

Data for the Capilano River are included for comparison with more southerly streams. A brief description of the characteristics of each stream and its topography is presented below.

Waddell Creek, California

Waddell Creek flows to the Pacific Ocean in central California. Approximately three miles upstream of its mouth the stream branches to a main west and east fork.

The stream is situated in the humid coast belt which receives most of its annual precipitation during December, January and February. Precipitation during the summer is light. These con- 


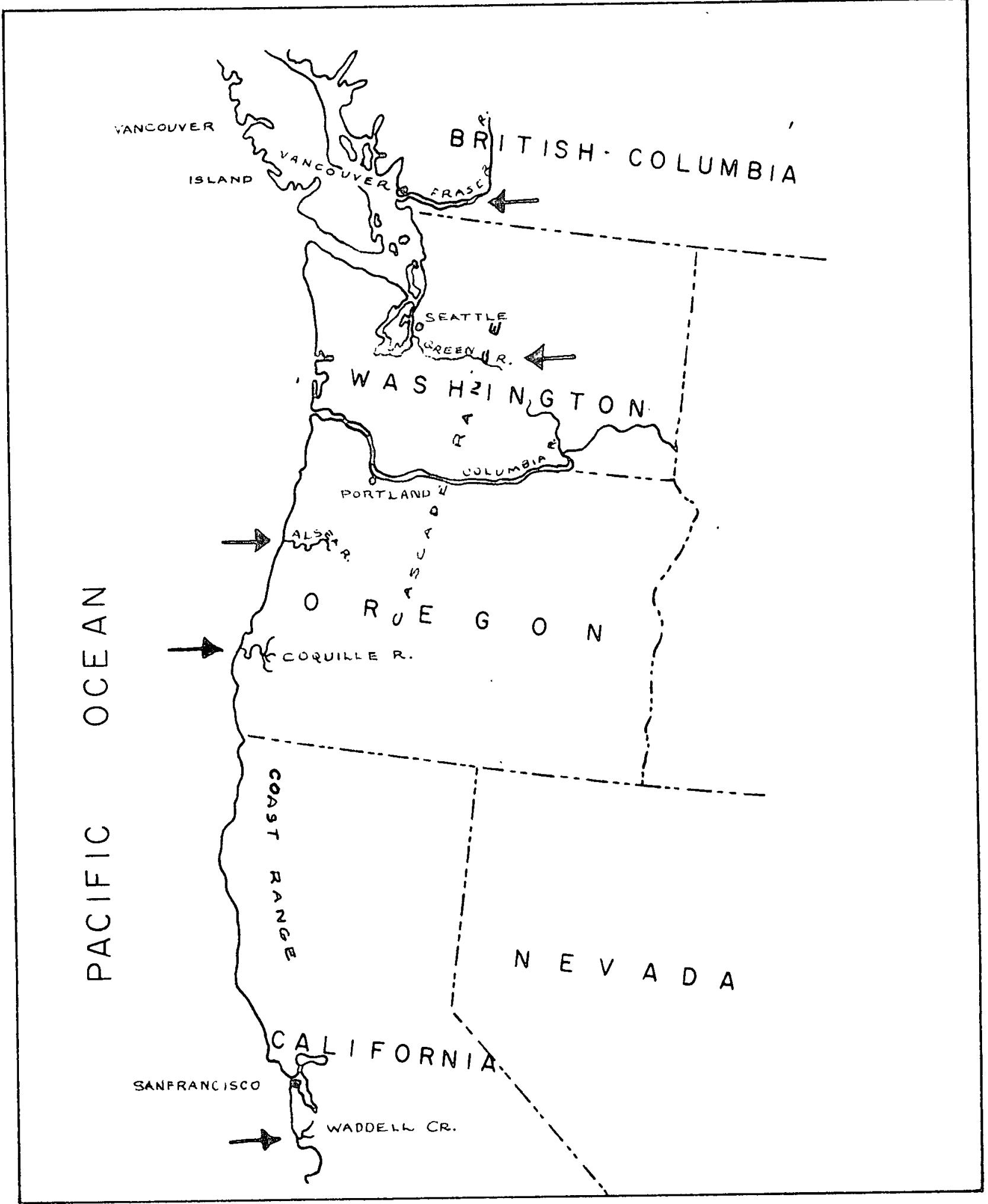

Figure 9. Location of the Pacific Coast study streams. 
Table VI. Physical characteristics of the Pacific coastal study streams

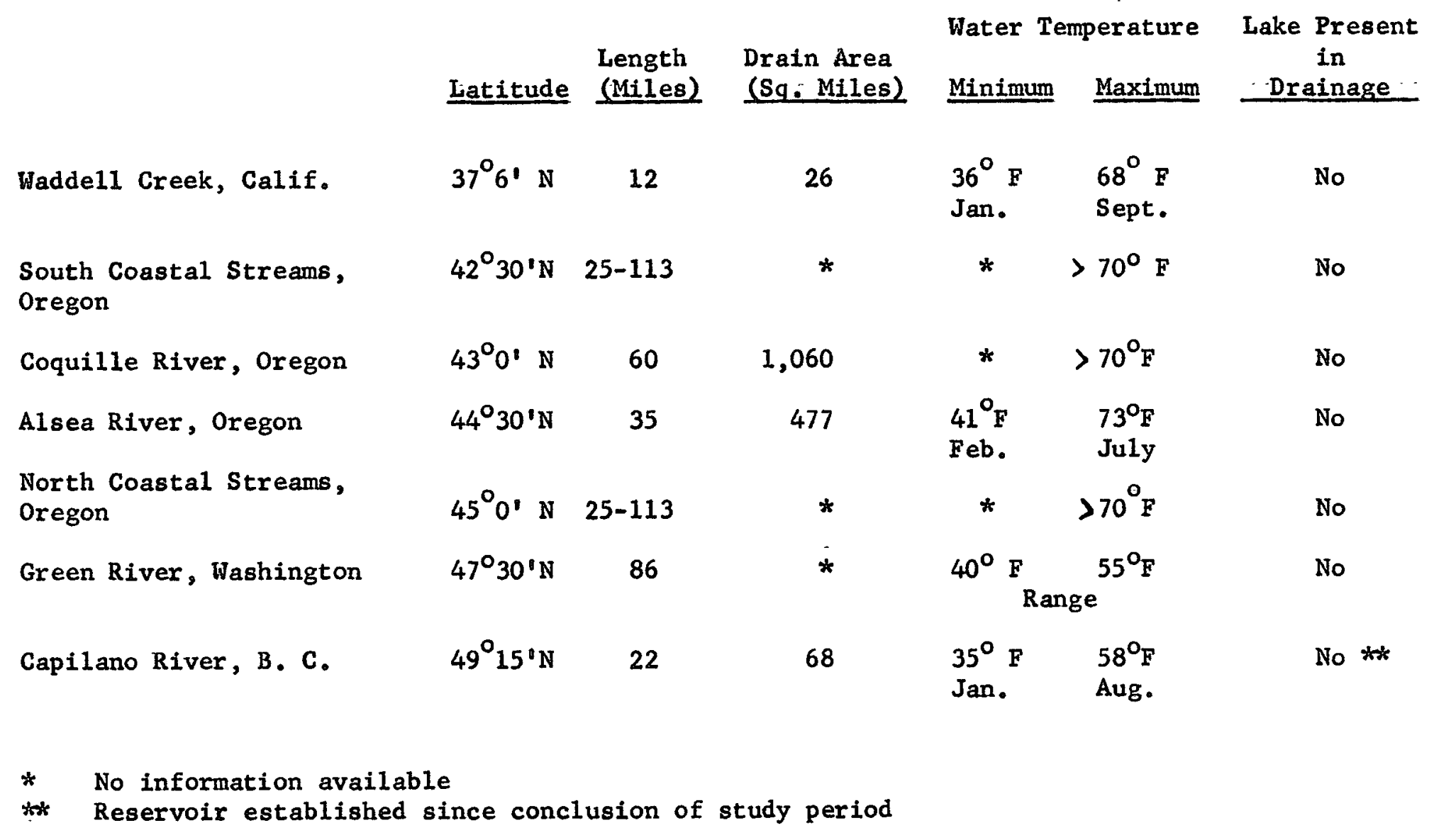


54

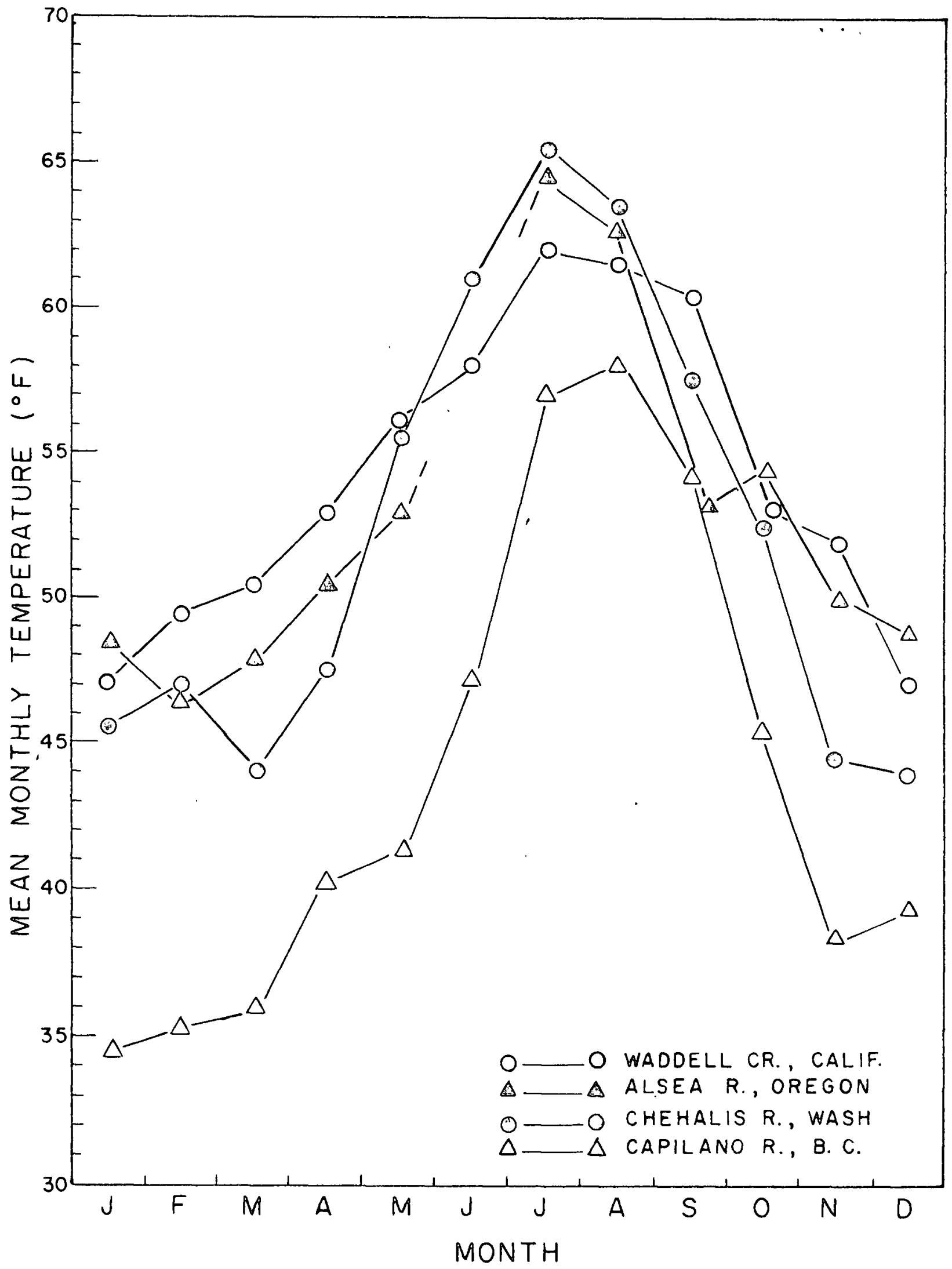

Figure 10. Mean monthly water temperatures for a complete year of record for some coastal study streams. 
ditions contribute to large variations in the flow of the stream. Typically, daily water flows range between 30 and 500 cfs from mid-December until mid-May, decrease to 5 cfs by the end of July and remain from 3 to 5 cfs until the heavy rains commence in mid-December.

The stream-bed in the headwater portions of the stream is composed of large boulders and bedrock; deep pools are numerous. The central regions of the stream are broader and contain fewer deep pools. The stream bed is composed of coarse rubble and sand. Most coastal California streams and some streams of the south coast of Oregon have a drowned mouth or "lagoon" which forms at the termination of the stream. The seaward sand-bar forming the lagoon at Waddell Creek opens and closes the stream mouth depending on stream flows, tides and wind and wave action. Normally the stream mouth is closed from late July or August until the heavy rains of mid-December appreciably increase stream flows.

Alsea River, Oregon

The Alsea River flows to the Pacific via a ten mile long estuary at Alsea Bay, Oregon. Four major tributaries contribute most of the steelhead trout production in the drainage. The stream beds of the upper tributary streams are composed largely of gravel and rubble areas; the main stream bed is composed largely of bedrock. No closure of the river mouth occurs in summer. 
Water flow of the river is characteristic of central Pacific coastal streams. Runoff is usually heavy during the period from October through April but decreases markedly in the summer months.

Streams of South Coastal, Central and North Coastal Oregon

Bali (1958) has compared the physical and biological features of 14 coastal streams of Oregon containing steelhead populations. He has noted that the physical characteristics of the streams along the coast of Oregon are similar. They are generally clear in spring, summer and fall, but most often become muddy in winter from heavy rains. The streams typically have moderately rapid flows and steep channel gradients. Similarities among life-history characteristics of some steelhead populations have allowed for grouping of these streams to four south coastal, one intermediate (Coquille River) and nine north coastal streams.

Green River, Washington

The Green River enters tidewater south of Seattle, Washington. The upper 65 miles of the stream flow rapidly through canyon and riffle areas of coarse gravel and boulders. The lower portion of the river flows more slowly over a bottom of mud and sand. Three major tributary streams are present. No water flow or temperature data are available from the 
Green River. However, water temperature data for the Chehalis River (in central coastal Washington) are presented in Figure 10, assuming that the data are generally representative of temperatures experienced in most larger streams in central coastal Washington. Water temperatures are lower than those recorded for California and Oregon. During the months of December and March mean monthly temperatures of slightly less than $45^{\circ} \mathrm{F}$ were experienced. Water temperatures apparently rise in the spring in parallel with those of Oregon and California, then decrease in the fall months at a slightly faster rate.

Capilano River, British Columbia

The physical features of the Capilano River were discussed previously (Page 23). Figure 10 shows that mean water temperatures are approximately $10^{\circ} \mathrm{F}$ lower than those of more southerly streams. This divergence is greatest during the winter and early spring months.

A complete year of water flow (volume) record for the Capilano River is presented in Figure 2. 


\section{STEELHEAD POPULATIONS}

Timing of Runs

A comparison of data from the study streams shows that in the central and southern parts of their geographic range, winter steelhead first enter and ascend streams to spawn during a relatively constant time period (October 15 to November 15). Numbers of samples reported throughout the capture period suggest that in south and north coastal streams near equal numbers of fish enter streams during December and January, the greatest number enter during February and thereafter numbers decrease. However, this study and others (Shapavalov and Taft, 1954) (Bali, 1958) have shown that variations in timing of stream entry and seasonal variations in timing of the bulk of the migration do exist. The existence of two peaks of stream entry at Waddell Creek, California, has been shown to be a consequence of migration timing of steelhead of particular age classes. This phenomenon has not been documented elsewhere although observations from the Green River, Washington (Pautzke and Meigs, 1940), suggest that a similar situation obtains there. Unfortunately, the anglers' samples utilized in this present study and those used by Bali in Oregon would tend to mask such an effect.

Spawning occurs in all study streams during April and early May. Capture of spawned fish or "kelts" commences shortly afterward. 
Sex Ratios and Repeat Spawning

Shapavalov and Taft (1954) have shown that when the sex ratio of a steelhead population as a whole is determined, consideration should be given to the complexities created by the multiplicity of life-history categories, differential survival of sexes among repeat spawners, and variations of behaviour within certain life-history categories. Unfortunately, a paucity of data often makes such a thorough study of these related factors impossible in the present study.

Table VII summarizes the data available on sex ratios and repeat spawning of some steelhead populations geographically separated by considerable distances along the Pacific coast of the United States and British Columbia.

It is apparent that the sex ratios of the steelhead populations do not change from the southern portion of their range to the more northern ones. The trapping records of shapavalov and Taft in California, Chapman (1957) in Oregon and Pautzke and Meigs (1940) in Washington show that a male:female sex ratio of near $1: 1$ is found among adult steelhead populations of these geographically separate areas. The greater proportion of females ( 1 male : 1.3 females) in the adult run to Wadde 11 Creek is largely a result of the influence of the disproportionate survival of female repeat spawners over males and the high incidence of repeat spawners in the total run.

A comparison of sex ratios obtained from sampling by trap- 
Table VII. Sex ratios and frequency of repeat spawning of steelhead captured from Pacific coastal study streams

\begin{tabular}{|c|c|c|c|c|}
\hline $\begin{array}{c}\text { Sex Ratio of } \\
\text { Total Run } \\
\text { Male: Female }\end{array}$ & $\begin{array}{c}\% \\
\text { Repeat } \\
\text { Spawners }\end{array}$ & $\begin{array}{c}\% \\
\text { Second } \\
\text { Spawners }\end{array}$ & $\begin{array}{c}\% \\
\text { Third } \\
\text { Spawners }\end{array}$ & $\begin{array}{c}\% \\
\text { Fourth } \\
\text { Spawners }\end{array}$ \\
\hline
\end{tabular}

Waddell Creek

California

(t)

$1: 1.13$

17.2

15.0

2.1

0.1

South Coast

Oregon

(a)

$1: 1.8$

53.3

36.3

14.1

3.0

Coquille River

Oregon

(a) $\quad 1: 1.4$

38.3

30.9

4.9

2.5

North Coast

Oregon

(a)

$1: 1.6-27.9$

Alsea River

Oregon

$1: 0.9$

27.9

19.5

6.3

1.9

Green River

Washington

(t) $\quad(1955-56) \quad$ (Av. 1953-55)

9.2

1.9

Chilliwack River British Columbia

(t) $\quad 1: 1$

South Coast

British Columbia

(a) $1: 1$

5.8

5.6

0.2

(a)

$1: 1.8$

11.0

(Av. 1949-57)

9.5

1.5

(t) Trapped

(a) Angled 
ping and angling may be obtained from Table VII. Angling apparently selects a greater proportion of female steelhead than is representative of the population, and therefore is unreliable as a method of determining the sex ratios of the total population. This view is supported by the findings of Larkin et al (1951) for rainbow trout at Paul Lake, British Columbia.

At Wadde11 Creek it was found that males predominated in the spawning run in the early months (November, December), and that females were more numerous in the latter portions of the run (January to March). Bali (1958) has reported similar findings for streams of south and north coastal Oregon. This situation has not been found to exist in other of the study streams. Within each study stream there is a sharp decline in numbers from second spawners to third spawners and fish spawning for a fourth time represent a negligible portion of the total run.

Survival following spawning has been found to be higher among females than among males. At Wadde11 Creek, 1.6 female steelhead returned for each male repeat spawner. Chapman has found that repeat spawners in the Alsea River were present in the ratio of one male to 2.5 females. Bali (1958), summarizing the results of a study of 14 Oregon coast streams has stated that "the females showed a greater survival after spawning than did the males...." Pautzke and Meigs (1940) reported that a sample of 99 Puget Sound steelhead had five repeat spawners present which had a sex ratio of one male to four 
females. The 65 repeat spawners reported previously for British Columbia study streams (Table II) had a sex ratio of one male to 4.4 females.

These data show conclusively that female steelhead survive the rigors of spawning much more successfully than do males. This fact explains, in part, the greater numbers of females captured by anglers. Within Oregon, Bali (1958) has related the greater number of female steelhead captured in south coastal than in north coastal streams to the higher survival of spawners in southern streams.

Table VII indicates that repeat spawning steelhead are fewer in number in north coastal populations. This trend supports the finding of Bali who has described a similar phenomenon for coastal streams of Oregon. Also, the ability of individual steelhead to return to spawn in successive years appears to decrease in more northern streams. No fourth spawning stee1head were reported from the Alsea River, Oregon, Washington or British Columbia.

Lengths and Life History Categories

The length which an individual steelhead attains at maturity is dependent upon its growth in the ocean environment and is largely independent of the size attained in fresh water (Maher, 1954). The amount of ocean growth is largely dependent upon the number of years spent in that environment before maturity, and may be modified by the fishes' previous spawning hist- 
ory and oceanic conditions. Chapman (1957) presented data which suggest that smolts of smaller sizes produce adults of the greatest ages at maturity. Bali (1958) has shown that along the coast of Oregon similarities exist among local steelhead populations which allow for their grouping as southern, central and northern populations. Among adults, northern fish had greater length and weight at maturity than southern fish, and fish from a central population (Coquille River) were intermediate in length and weight. This comparison is expanded here to indicate the length differences of mature steelhead which exist throughout a greater portion of their geographic range. Shapavalov and Taft (1954) have studied lengths and weights of all adult steelhead captured during a nine year trapping study at Waddell Creek. Analysis of these data has shown that growth varied with abundance, among different life-history categories and between sexes. The mean length of all adult winter steelhead captured in the upstream trap in all years of study was 22.9 inches.

In Oregon the mean length of all steelhead captured from the Alsea River by Chapman in a tagging study extending from 1951 to 1956 was 25.5 inches. Bali, analysing angler sample data from numerous watersheds of coastal Oregon found that the mean length of fish from the southern region was 26.1 inches, from the central region 26.3 inches and from the northern region 26.5 inches.

In British Columbia, Maher (1954) analysing anglers' samples 
from the Chilliwack River found the mean length of all adults captured to be 29.7 inches. The mean length of all fish sampled for the present study was 28.3 inches. If the possible bias of anglers toward retaining and reporting upon larger fish may be disregarded, it is apparent that the mean size of steelhead entering streams to spawn increases in more northerly areas. This effect is apparent at least from central California to southern British Columbia.

The differences noted in mean lengths of geographically separate steelhead populations can be explained, at least in part, by a tendency for fish from more northern areas to spend a greater length of time in the ocean before sexual maturity is attained. Table VIII illustrates this trend. Steelhead which have spent only one year in salt water decline from 46.5 percent of the total adult population at Waddell Creek, California, to only 0.5 percent of the adult population in the Chilliwack River, British Columbia. Numbers of /2 fish remain fairly constant in each area, while a progressively greater number of $/ 3$ fish are found in more northern areas. Numbers of /4 fish are fairly constant throughout their range.

Data from scale samples of steelhead taken over a large portion of their geographic range indicate that fish comprising the smolt migration achieve this condition at a variety of ages and that differing percentages of fish of the same age groups are present in smolt migrations. Ages at migration of smolts from different geographic locations are presented in Table VIII. 
Table VIII. Mean lengths and age composition of adult steelhead captured within coastal study streams.

\begin{tabular}{|c|c|c|c|c|c|c|c|c|c|}
\hline & $\begin{array}{c}\text { Mean } \\
\text { Length }\end{array}$ & & eshwate & Reside & & & twater & Reside & \\
\hline & (inches) & $1 /$ & $2 /$ & $3 /$ & 4/ & $/ 1$ & $/ 2$ & $/ 3$ & 14 \\
\hline Waddell Creek, Calif. & 22.9 & $10.1 \%$ & $72.3 \%$ & $16.7 \%$ & $0.9 \%$ & $46.5 \%$ & $47.0 \%$ & $6.0 \%$ & $0.5 \%$ \\
\hline Alsea River, Oregon & 25.5 & 1.4 & 80.2 & 18.2 & 0.2 & 5.4 & 66.4 & 25.6 & 2.6 \\
\hline $\begin{array}{l}\text { South Coastal Streams } \\
\text { Oregon }\end{array}$ & 26.1 & 0.7 & 43.0 & 53.3 & 3.0 & 85.2 & 14.1 & 0.7 & - \\
\hline $\begin{array}{l}\text { Central Coastal } \\
\text { Stream, Oregon }\end{array}$ & 26.3 & - & 54.4 & 44.4 & 1.2 & 50.6 & 44.4 & 5.0 & - \\
\hline $\begin{array}{l}\text { North Coastal Streams } \\
\text { Oregon }\end{array}$ & 26.5 & 6.9 & 71.7 & 21.4 & - & 25.0 & 64.7 & 10.3 & - \\
\hline Green River, Wash. & * & 16.0 & 75.0 & 9.0 & - & 7.0 & 66.0 & 25.0 & - \\
\hline Chilliwack River, B.C. & 29.7 & 2.0 & 62.6 & 35.0 & 0.4 & 0.5 & 49.9 & 49.1 & 0.5 \\
\hline $\begin{array}{l}\text { Southern British } \\
\text { Columbia Study Streams }\end{array}$ & 28.3 & 1.8 & 39.9 & 54.9 & 3.4 & 1.1 & 59.1 & 37.2 & 2.6 \\
\hline
\end{tabular}

* Data not available 
Steelhead smolts descend to the sea at ages from one to four years, with the bulk of the migrants at two or three years of age. Studies from various coastal streams from northern California to southern British Columbia show that yearling migrants constitute between 0.0 and 16.0 percent of the various populations. In most instances two-year-old migrants are in the majority, constituting between 39.9 and 80.2 percent of the various smolt populations. Three-year-old smolts are generally present in lesser numbers than two-year-old smolts, although exceptions occur. They comprise between 9.0 and 54.9 percent of the various populations. Four-year-old migrants are very few in number; in no instance do they comprise more than 3.4 percent of any population. 


\section{DISCUSSION}

Life-histories of steelhead trout are complex and greatly varied. The first part of the present study has examined variation in life-history characteristics within and amongst populations in a restricted area of British Columbia. The second part has considered the variation between steelhead populations along the coast of North America and has suggested that divergence of some characteristics is parallel to geographic separation of the population studied. Maher (1954) has suggested that the variety of life-history patterns exhibited by this species may represent an adaptation which allows steelhead trout populations to survive through years of extremely adverse conditions. This variation has probably allowed for the southward extension of sizeable steelhead populations beyond that experienced by most Pacific salmon. It is also possible that flexibility of steelhead population characteristics allows for the existence of small populations within many stream systems uninhabited by some species of Pacific salmon.

WINTER AND SUMMER STEELHEAD

Steelhead may be divided into two different groups by differences in behaviour prior to spawning. Winter steelhead enter streams to spawn during the period October to April to spawn in March and April. Summer steelhead enter streams from May to September to spawn during March and April. They are 
further distinguished in that winter steelhead are found in a larger number of coastal streams than are summer steelhead. Life-history characteristics such as sex-ratios, frequency of repeat spawning, adult lengths and years of fresh and saltwater residence are similar between the two populations.

Smith (1960) has described differences in physical appearance among spawning summer and winter steelhead from the Capilano River. Summer steelhead exhibited a typical bright red "rainbow" coloration on the gill covers and along the lateral line, and males had well-developed hooked snouts. Both of these characteristics were largely absent among winter fish spawning at the same time. Of greatest interest is the finding by Smith (1960) that among a sample of 30 summer and winter steelhead, all summer fish examined exhibited gill raker tips which were flattened and bifurcated. Winter fish did not exhibit this characteristic. These findings suggest that definitive morphological differences may exist, at least among adult forms, which will distinguish these populations more adequately. Also, aritifically spawned juvenile steelhead of "winter" and "summer" stock have been planted in the Capilano River. To date returning adults have been in the same stages of sexual maturity as were their parents at capture. That is, none of the summer steelheads' progeny returned as winter fish, and none of the winter steelheads' progeny returned as summer fish. The populations appear to be separated by strongly heritable characteristics. 
Adult sockeye salmon exhibit "racial" variations in timing of entry to spawning streams. Gilhousen (1960) summarized information relating to the timing of ascent of races of sockeye salmon within the Fraser River system. He has concluded that "normal" or mean timing has arisen through evolution by selective processes, the mean value representing the optimum point of survival conditions for a particular race. He has concluded that sockeye maturation is a response to the pattern of changing length of day, and individual populations which spawn at different times must differ genetically in their response to changes in day length.

Belding and Kitson (1934) discussed possible causative conditions within streams which may operate to encourage development of observed early and late run Atlantic salmon. Fall runs of Atlantic salmon (corresponding most closely to winterrun steelhead) were observed to occur almost exclusively in small rivers with spawning grounds near to the stream mouth. Variations in water flows and temperature resulted in only temporary variations in salmon migration patterns. of greatest significance was the finding that early run fish had more highly developed gonads than did salmon which entered streams later. Also, early run and late run salmon showed practically no difference in mean fork length in spite of the (assumed) longer feeding period of the latter in salt water. It was concluded that early river entry is associated with precocity or accelerated development in Atlantic salmon. 
Precocious gonadal development apparently is not a prime cause of upstream migration of summer steelhead. Examination of fish sampled at the Cailano River trapping facilities has shown gonads to be but slightly developed. Also, it is difficult to explain the early migrations of summer steelhead on a basis of selection for optimum stream conditions. During summer and early autumn months stream water levels are low and water temperatures are high, conditions which do not favour survival of salmonids.

Chapman (personal communication) has observed that within coastal streams of Oregon, summer steelhead are restricted to streams which contain deep pools with slow moving water within which the fish may hold during periods of summer and autumn low water volumes.

Within British Columbia, observation of the topography of streams containing populations of summer steelhead suggests that natural temporary barriers (small waterfalls, stretches of extremely turbulent water) which are navigable by fish only at summer water flows may be present within all streams which contain these populations. Partial barriers are present within the Seymour and Coquihalla Rivers, and such a barrier was present in the Capilano River prior to establishment of a reservoir. Barriers of this type may allow upstream passage of only the early, more vigorous stream entrants. This condition. would tend to perpetuate an isolated population of separately reproducing, early migrating adult steelhead, the so-called summer steelhead. 
TIMING OF STREAM ENTRY

Populations of steelhead trout which inhabit tributaries of the same river system (i.e., lower Fraser River) and those which inhabit coastal streams within a restricted area (i.e., coastal Oregon) exhibit differences in behaviour despite their proximity to each other. The timing of stream entry of populations of winter and summer steelhead is greatly divergent. Also, discreet populations of winter steelhead first entered the British Columbia study streams during different time intervals. The dates of first capture extended from November 15 to January $I$ except in the Cheakamus River where the first capture of winter fish was reported after April 1.

Instances of delayed entry to streams of winter steelhead similar to that observed for the Cheakamus River have not been reported elsewhere. This late winter run coincides with the delayed freshet condition which exists within the stream (Figure 2). Correlation of the late run with the increased water volumes suggests that a freshet condition is required to initiate upstream movement of spawners. Briggs (1953, studying the winter steelhead population of the Mad River, California, found that steelhead enter streams in greatest numbers during periods of temporary high water flows (freshet conditions) accompanied by a brief rise in water temperature. Although timing of stream entry may vary within a restricted area, there is no evidence of a progressive trend toward early or late stream entry between geographically separated 
populations.

Shapavalov and Taft (1954) have reported distinct "peak" numbers of steelhead entering Waddell Creek at intervals. Anglers have reported similar occurances for other streams (Pautzke and Meigs, 1940), but this phenomena is difficult to detect in creel census studies where angling effort varies with favourable and unfavourable water and weather conditions.

\section{SEX RATIOS}

Almost twice as many female as male steelhead were captured from study streams within southern British Columbia. A similar situation prevails within anglers' samples from along the Pacific coast. This sex ratio conflicts with the near 1:1 ratio obtained from trapping studies (Shapavalov and Taft, 1954) (Chapman, 1957). Apparently, sport fisheries select for females in anadramous populations of rainbow trout.

Two factors are known to emphasize this observed selectivity. First, frequency of repeat spawning is greater for female steelhead than for males. The slightly greater numbers of females present in populations because of their greater survival following spawning results in capture of greater numbers of this sex by anglers. Within southern British Columbia repeat spawning was most frequent among steelhead from Cheakamus River; here also the ratio of females to males captured was greatest. Second, males deteriorate in appearance to a greater extent than females as spawning approaches, therefore, greater 
numbers of males than females are released alive during the later portion of the spawning run.

Shapavalov and Taft (1954) and Bali (1958) have reported entry to streams of a greater proportion of males than females during the early (October 1 to January 1) portion of the spawning run of winter steelhead. This condition was not discovered for streams of southern British Columbia, nor from data presented by Maher (1954).

\section{REPEAT SPAWNING}

Repeat spawning has been found to range from 5 to 31.3 percent among winter-run steelhead populations and between 4.4 and 6.3 percent among summer-run steelhead populations in lower coastal British Columbia.

The high incidence of repeat spawning observed for fish from the Cheakamus River ( 31.3 percent) may be a consequence of a contracted term of fresh-water residence prior to spawning, as few fish enter the stream to spawn until April 1. Such a thesis assumes that a fresh-water existence for adult anadromous trout is more rigorous than is a salt-water existence. This assumption is supported by the observation that within streams of southern British Columbia the incidence of repeat spawning is slightly greater for winter steelhead than summer steelhead. The latter spend the greatest length of time in fresh water prior to spawning. 
Along the Pacific coast females more commonly survive to spawn a second or third time than do males, and this tendency increases from southern to northern areas. Idler and Clemens (1959) measured loss of fat, protein and energy (in calories per kilogram of weight) of sockeye salmon during their spawning migration from the sea to lakes in the upper Fraser River system. Females from both the Chilko and Stuart runs utilized a higher percentage of fats, proteins and energy reserves than did their male counterparts. This finding agrees with Belding (1934) who determined that the percentage of body weight lost by spawning female Atlantic salmon in the Mirimichi River, New Brunswick, was greater than that lost by males. It may be assumed that female steelhead trout lose a greater percentage of body weight during the spawning migration, as do members of some other salmonid populations. Probably the lower survival of males is related to causes other than condition factors. These other causes are not known precisely, but they may be associated with early stream entry (as at Waddell Creek and within coastal streams of Oregon), a tendency to remain on the spawning grounds for extended periods of time or fighting in defence of spawning territory. 
FORK LENGTHS

Mean fork lengths of populations of winter and summer steelhead within a limited geographic range were found to vary only slightly. However, winter steelhead from the Cheakamus River were larger than fish of all other populations. This greater mean length is a corollary of the high incidence of repeat spawning (and therefore the greater number of years of salt-water residence) of the individuals sampled. The summer steelhead of the Coquihalla River had the lowest mean length, a consequence of a shorter mean time of salt-water residence than exhibited by other summer steelhead populations.

Mean fork lengths of steelhead populations from streams along the Pacific coast increase from central California to southern British Columbia. This may be a consequence of the tendency for steelhead to spend more years in salt-water in more northern than southern areas. Marr (1943) observed that older pink, chum and coho salmon from various Pacific coast watersheds are more abundant in northern areas of their range of distribution.

\section{LIFE-HISTORY CATEGORIES}

This study, and others, show that the number of years which steelhead from the same or closely associated watersheds spend in fresh and salt water is not constant. Juvenile stee1head spend from one to four years in fresh water prior to migra- 
tion, and one to four years is spent in salt water prior to return for spawning. The youngest mature steelhead captured was three years of age; the oldest was seven.

The ratios of years spent in fresh and salt water by steelhead is not constant along the Pacific coast. In all streams except those of south coastal British Columbia two-year-old smolts predominate. Numbers of three-year-old smolts increase in northern areas.

Some instances (Shapavalov and Taft, 1954, Bali, 1958) of large numbers of three-year-old smolts have been observed to result from delay of smolt exit by "trapping" through closing of bars at stream mouths in California and southern Oregon. Fish with longer salt-water residence are progressively more abundant in northern areas.

\section{CONTROL OF POPULATION CHARACTERISTICS}

Figure 11 illustrates the manner in which life-history characteristics of steelhead populations vary along the Pacific coast. Change. in mean monthly water temperature is included as a possible environmental factor governing population characteristics. The greater mean adult lengths observed among northern steelhead populations is a result of the longer oceanic growing period of these fish. Lengths of adult steelhead are largely independent of lengths obtained in fresh water. The decrease in frequency of repeat spawning noted for north coastal populations is probably related to the greater number 


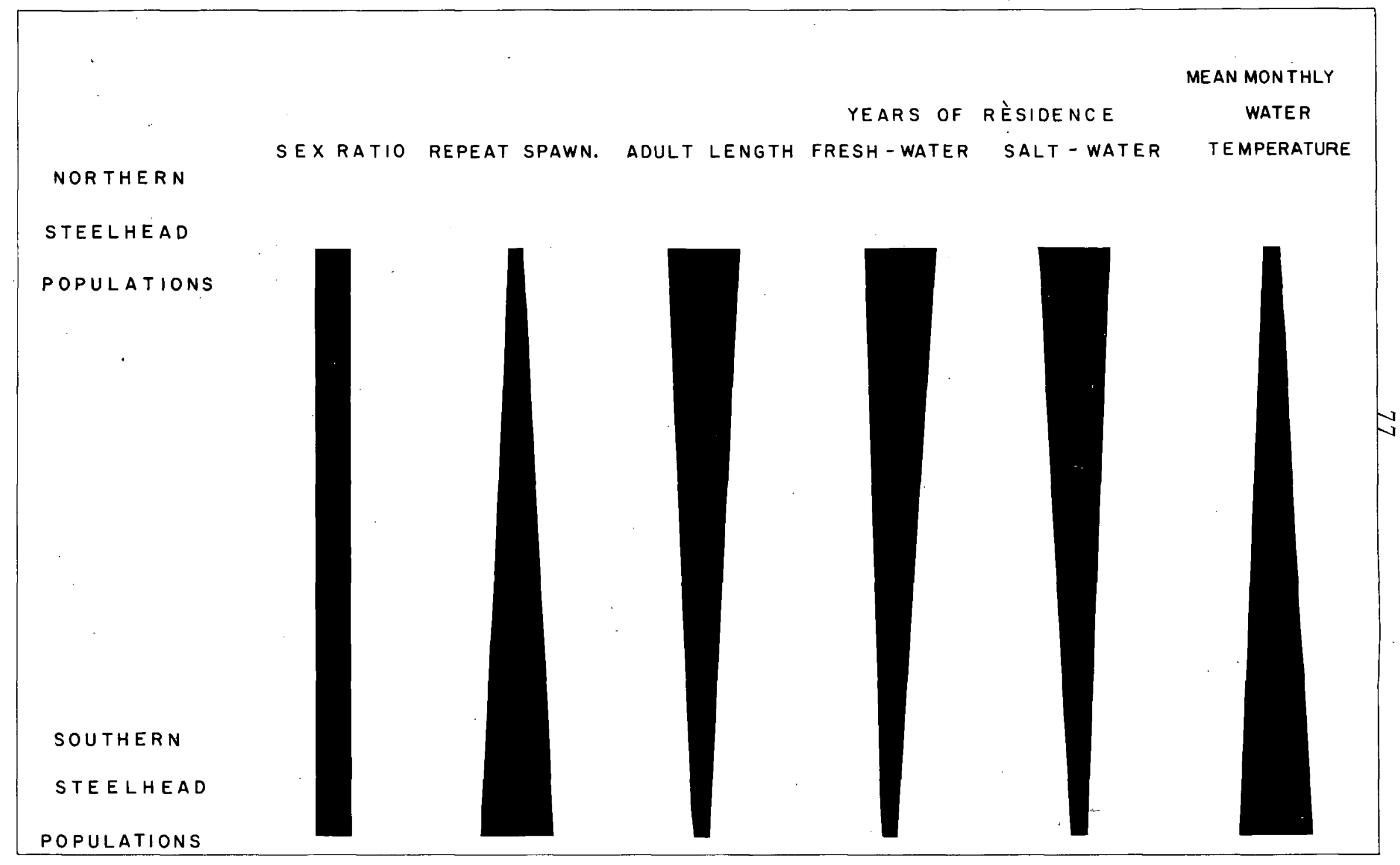

Figure 11. Schematic representation of changes in life-history attributes of steelhead populations, and mean stream temperatures, along the Paciflc coast; thick portions of the pointers suggest greatest frequency or amount of an attribute, thin portion, the least. 
of years which fish of these populations spend in both fresh and salt water. The possibility of survival to subsequent spawning migrations decreases as the age of steelhead increases. The divergence of characteristics may be related to genetic or environmental influences, or both. Marr (1943) showed that some species of Pacific salmon diverge progressively in some life-history characteristics throughout their range. Svardson (1954) demonstrated that smolt age of Atlantic salmon within the Baltic Sea increased from south to north.

Elson (1957) has suggested for Atlantic salmon that the age at which smolts migrate to sea is governed by their rate of growth in fresh water. Chapman (1957) has related the age of steelhead smolts to the number of years which they spent in salt water; the youngest (and presumably most rapid-growing) smolts spend the shortest periods in salt water.

Ricker (1959) states that the variation which Pacific salmon and steelhead trout exhibit has both a genetic and environmental basis, and "scores of genetically different stocks of a species can exist in one and the same river system, half a dozen or more even within a single lake". This view is supported by Vernon (1957) who has determined that several different races of kokanee exist within Kootenay Lake, British Columbia, but he has suggested that growth, age at maturity, and morphological differences are genetically controlled. Whitese1 (personal communication) has postulated that environmental control of life-history pattern may operate in steelhead 
producing streams which possess headwater lakes. He believes that the moderation of downstream temperatures and water volumes provides a most suitable environment within which steelhead may grow, prior to downstream migration.

The differences in mean temperatures of streams containing salmonid populations has been suggested by Alm (1959) as a major factor in regulating growth and maturity of Atlantic salmon. Differences in stream temperatures along the coast of North America have been demonstrated in this study (Figure 10). However, other environmental factors which vary geographically may act to regulate growth and migration ages.

It is unlikely that changes in frequency of repeat spawning among populations is related to variations in mean temperatures.

Other factors governing changes in steelhead population characteristics along the coast of North America might be the influence of latitudinal changes in day lengths upon feeding habits or pituitary stimulation. Characteristic differences may arise from the action of a combination of several environmental variables related to climatology and the fresh and saltwater environment of the fish. 


\section{LITERATURE CITED}

Alm, G., 1959. Connection between maturity, size and age in fishes. Institute of Freshwater Research, Drottningholm, Report No. 40: 5-145.

Bali, J. M., 1958. Scale analyses of steelhead trout, Salmo gairdneri gairdneri Richardson, from various coastal watersheds of Oregon. M.Sc. thesis, Oregon State College.

Belding, D. L., 1934. The cause of the high mortality in the Atlantic salmon after spawning. Trans. Amer. Fish. Soc., 64 : 219-224.

Belding, D. L. and J. A. Kitson, 1934. Spring-run and fallrun Atlantic salmon. Trans. Amer. Fish. Soc., 64 : $225-230$.

Briggs, J. C., 1953. The behavior and reproduction of salmonid fishes in a small coastal stream. California Dept. Fish and Gam, Fish Bull., No. 94.

Chapman, D. W., 1957. Studies on age, growth, and migration of steelhead trout, Salmo gairdneri gairdneri, in the Alsea River, Oregon. Masters thesis, Oregon State College.

Elson, P.F., 1957. The importance of size in the change from parr to smolt in Atlantic salmon. The Canadian Fish Culturist, No. $21: 1-6$.

Huntsman, A. G., 1939. Salmon for angling in the Margaree River. Bull. Fish. Res. Bd. Canada, No. 57.

Idler, D. R. and W. A. Clemens, 1959. The energy expenditures of Fraser River sockeye salmon during the spawning migration to Chilko and Stuart lakes. International Pacific Salmon Fisheries Commission, Prog. Rep.

Larkin, P. A., 1949. Report on relative efficiences of various types of fishing gear with special reference to Kamloops trout. Report of Provincial Game Convention.

Larkin, P. A., 1950. Report on the preliminary survey of the steelhead of the lower Fraser River. Reprinted from Report of the Provincial Game Commission, 1948. 
Larkin, P.A., G. C. Anderson, W. A. Clemens, and

D. C. G. Mackay, 1950. The production of Kamloops trout (Salmo gairdnerii kamloops, Jordan) in Paul Lake, British Columbia. University of British Columbia and British Columbia Game Department.

Gilhousen, P., 1960. Migratory behaviour of adult Fraser River sockeye. International Pacific Salmon Fisheries Commission, Progress Report.

Maher, F. P., 1954. Life history of the steelhead as interpreted from the scales. M.A. thesis, University of British Columbia.

Marr, J. C., 1943. Age, length, and weight studies of three species of Columbia River salmon (Oncorhynchus keta, 0 . gorbuscha, and 0. kisutch). Stanford Ichthy. Bu11., Vo1. 2, No. $6: 157-197$.

Milne, D. J., 1948. The growth, morphology and relationship of the species of Pacific salmon and the steelhead trout. Doctoral thesis, McGill University.

Neave, F., 1949. Game fish populations of the Cowichan River. Bull Fish. Res. Bd. Canada, No. 84 .

Pautzke, C. F. and R. C. Meigs, 1940. Studies on the life history of the Puget Sound steelhead trout (Salmo gairdnerii). Trans. Amer. Fish. Soc., $70: \frac{209-220 .}{2}$

Ricker, W. E., 1959. Evidence for environmental and genetic influence on certain characters which distinguish stocks of the Pacific salmons and steelhead trout. Fish. Res. Bd. Canada (mimeo.).

Shapavalov, Leo, and A. C. Taft, 1954. The life histories of the steelhead rainbow trout (Salmo gairdneri gairdneri) and silver salmon (Oncorhynchus kisutch) with special reference to Waddell Creek, California, and recommendations regarding their management. Calif. Dept. Fish and Game, Fish. Bull. No. 98.

Smith, S. B., 1960. A note on two stocks of steethead trout (Salmo gairdneri) in Capilano River, British Columbia. J. Fish. Res. Bd. Canada, 17 (5) : 739-742.

Svardson, G., 1954. Salmon stock fluctuations in the Baltic Sea. Institute of Freshwater Research, Drottningholm, Report No. 36, : 226-262.

Vernon, E. H., 1957. Morphometric comparison of three races of kokanee (Oncorhynchus nerka) within a large British Columbia lake. J. Fish. Res. Bd. Canada, 14 (4) : 573-598. 


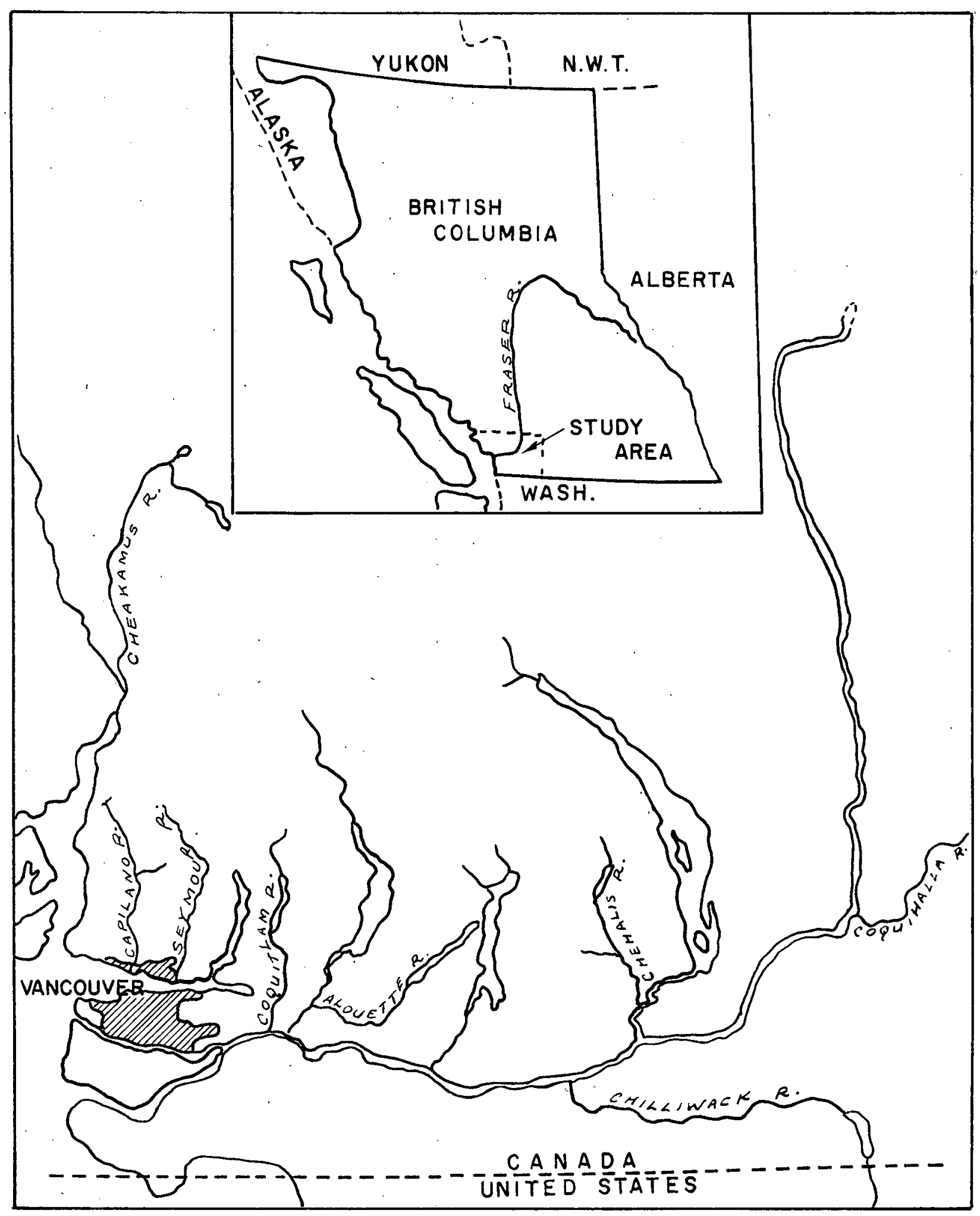




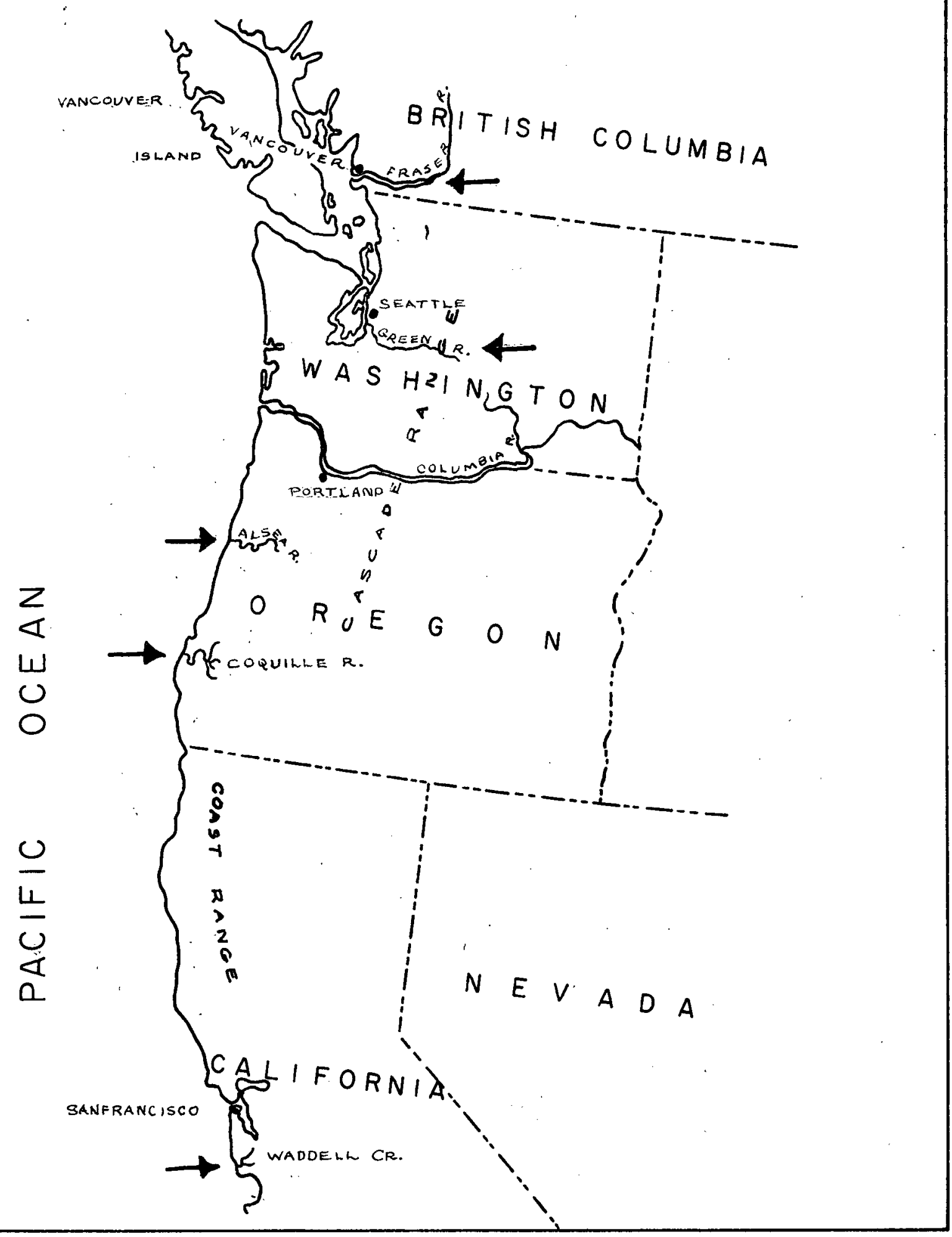

LES Q7

1961 A67 WA U2
FIG: 


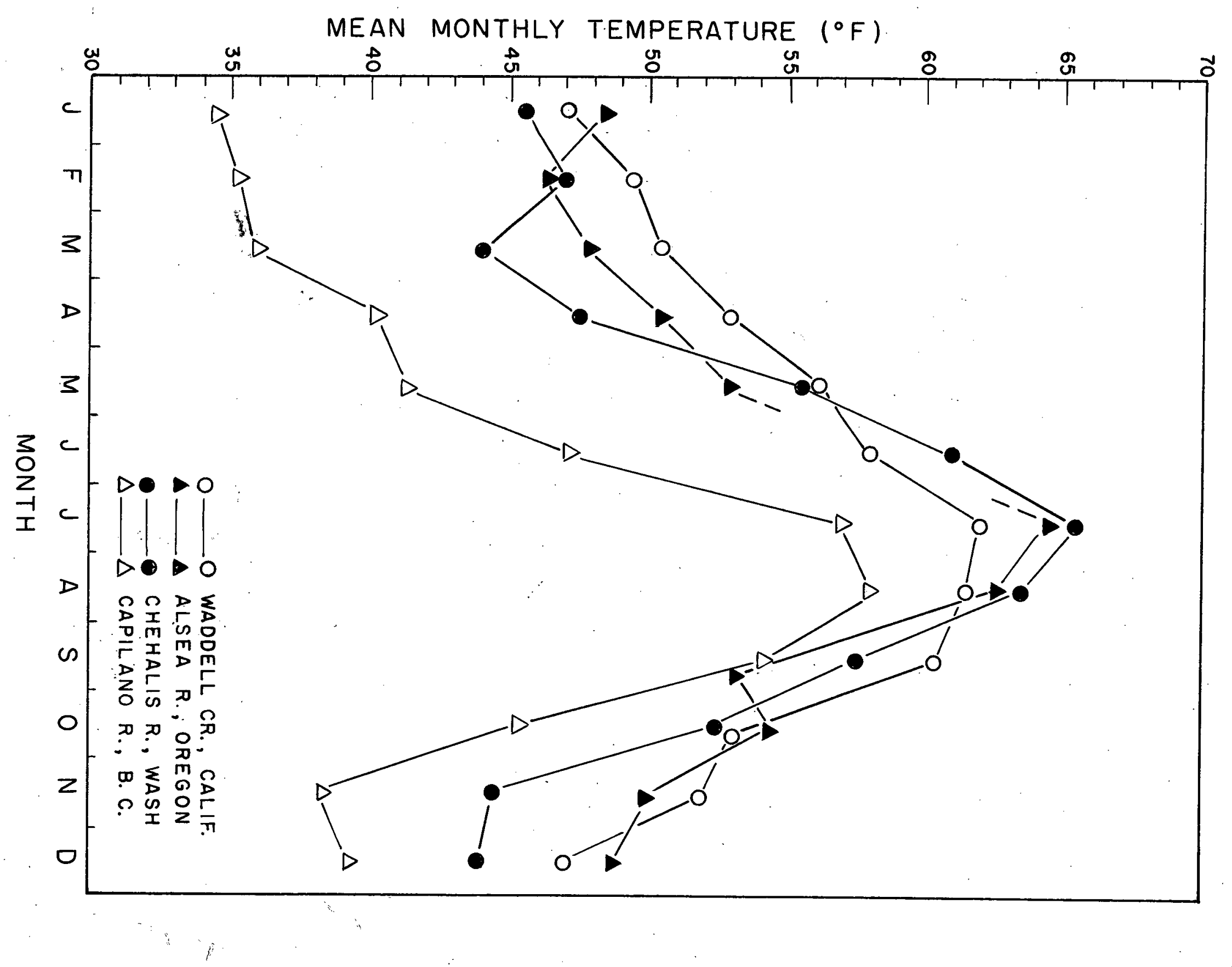

